Nova Southeastern University

$1-1-2009$

\title{
New Perspectives on Ecological Mechanisms Affecting Coral Recruitment on Reefs
}

\author{
Raphael Ritson-Williams \\ Smithsonian Marine Station - Fort Pierce \\ Suzanne N. Arnold \\ University of Maine \\ Nicole D. Fogarty \\ Florida State University, <<span class="elink">fogartyn@uncw.edu \\ Robert S. Steneck \\ University of Maine \\ Mark J.A. Vermeij \\ CARMABI - The Netherlands \\ See next page for additional authors
}

Find out more information about Nova Southeastern University and the Halmos College of Natural Sciences and Oceanography.

Follow this and additional works at: https://nsuworks.nova.edu/occ_facarticles

Part of the Marine Biology Commons, and the Oceanography and Atmospheric Sciences and Meteorology Commons

\section{NSUWorks Citation}

Raphael Ritson-Williams, Suzanne N. Arnold, Nicole D. Fogarty, Robert S. Steneck, Mark J. A. Vermeij, and Valerie J. Paul. 2009. New Perspectives on Ecological Mechanisms Affecting Coral Recruitment on Reefs .Smithsonian Contributions to the Marine Sciences : 437 -457. https://nsuworks.nova.edu/occ_facarticles/503. 


\section{Authors}

Valerie J. Paul

Smithsonian Marine Station - Fort Pierce 


\title{
New Perspectives on Ecological Mechanisms Affecting Coral Recruitment on Reefs
}

\author{
Raphael Ritson-Williams, Suzanne N. Arnold, \\ Nicole D. Fogarty, Robert S. Steneck, \\ Mark J. A. Vermeij, and Valerie J. Paul
}

Raphael Ritson-Williams and Valerie J. Paul, Smithsonian Marine Station at Fort Pierce, 701 Seaway Drive, Fort Pierce, Florida 34949, USA. Suzanne N. Arnold and Robert S. Steneck, University of Maine, School of Marine Sciences, Darling Marine Center, Walpole, Maine 04573, USA. Nicole D. Fogarty, Department of Biological Science, Florida State University, Tallahassee, Florida 32306-4295, USA. Mark J. A. Vermeij, CARMABI, Piscaderabaai z/n, Curacao, Netherlands Antilles. Corresponding author: R. RitsonWilliams (williams@si.edu). Manuscript received 9 June 2008; accepted 20 April 2009.

\begin{abstract}
Coral mortality has increased in recent decades, making coral recruitment more important than ever in sustaining coral reef ecosystems and contributing to their resilience. This review summarizes existing information on ecological factors affecting scleractinian coral recruitment. Successful recruitment requires the survival of coral offspring through sequential life history stages. Larval availability, successful settlement, and post-settlement survival and growth are all necessary for the addition of new coral individuals to a reef and ultimately maintenance or recovery of coral reef ecosystems. As environmental conditions continue to become more hostile to corals on a global scale, further research on fertilization ecology, connectivity, larval condition, positive and negative cues influencing substrate selection, and post-settlement ecology will be critical to our ability to manage these diverse ecosystems for recovery. A better understanding of the ecological factors influencing coral recruitment is fundamental to coral reef ecology and management.
\end{abstract}

\section{INTRODUCTION}

Coral reefs are facing unprecedented human impacts and continuing acute and chronic threats that can impact community structure (Nyström et al., 2000). Their ability to resist such changes or to recover from them defines their "resilience" (sensu Holling, 1973). Unfortunately, coral reef ecosystems can be resilient in either the more desirable coral-dominated phase or in the less desirable algal-dominated phase (Hughes et al., 2005). Although we know much about what causes undesirable "phase shifts" (Done, 1992; Hughes, 1994; Pandolfi et al., 2005), we know relatively little about what drives coral community recovery (Connell, 1997).

Scleractinian corals are uniquely important to coral reef ecosystems as ecosystem engineers that structure the habitat (Jones et al., 1994, 1997). The abundance of live coral drives key ecological processes in the wider coral reef community, such as providing recruitment habitat for reef fish, lobsters, and sea urchins (Lee, 2006; Mumby and Steneck, 2008). In the past 30 years, the percent cover of live coral has decreased on a global scale (Gardner et al., 2003; Bruno and Selig, 2007), raising the question: How can we increase the number of corals in these ecosystems for recovery? 
Larval settlement (when they first attach to the benthos) and subsequent survival (recruitment) are processes that can control marine population dynamics (Gaines and Roughgarden, 1985; Doherty and Fowler, 1994; Palma et al., 1999). Although corals can reproduce clonally (Fautin, 2003; Baums et al., 2006), recruitment resulting from sexual reproduction is the primary means of recolonization for most species (Connell et al., 1997) and adds genetic variation to coral populations, which may increase survival of a species. Coral settlement followed by subsequent recruit survival and growth maintains coral populations and is necessary for coral reef recovery. For this cycle to occur on any given reef, larval survival and recruitment are dependent on a sequence of three phases: (1) larval availability, which integrates gamete production, fertilization success, and connectivity; (2) settlement ecology, which relates to larval condition and substrate selection behavior; and (3) post-settlement ecology, including substrate-specific survival and growth (Figure 1).

This review summarizes existing information on ecological factors affecting scleractinian corals during these first three phases of their life, covering the period from gamete release to juvenile coral colonies (typically described as $<40 \mathrm{~mm}$ ). We discuss factors that are critical for coral recruitment success, and where insufficient data exist, we draw parallels to concepts that have been developed for other marine larvae or adult corals and briefly discuss their relevance for the early life history stages of corals.

\section{LARVAL AVAILABILITY}

Larval supply to a reef depends on sequential processes of gamete production, fertilization success, and larval transport (i.e., larval dispersal and connectivity). Basic life history traits of corals can greatly influence the range of strategies that are used to ensure larval availability. Scleractinians have two main reproductive modes: brooding, where sperm are released into the water column and taken in by conspecifics for internal fertilization, and broadcast spawning, wherein both egg and sperm are released into the environment so that fertilization occurs externally, that is, in the water column (Figure 2; Fadlallah, 1983; Szmant, 1986; Richmond and Hunter, 1990; Richmond, 1997).

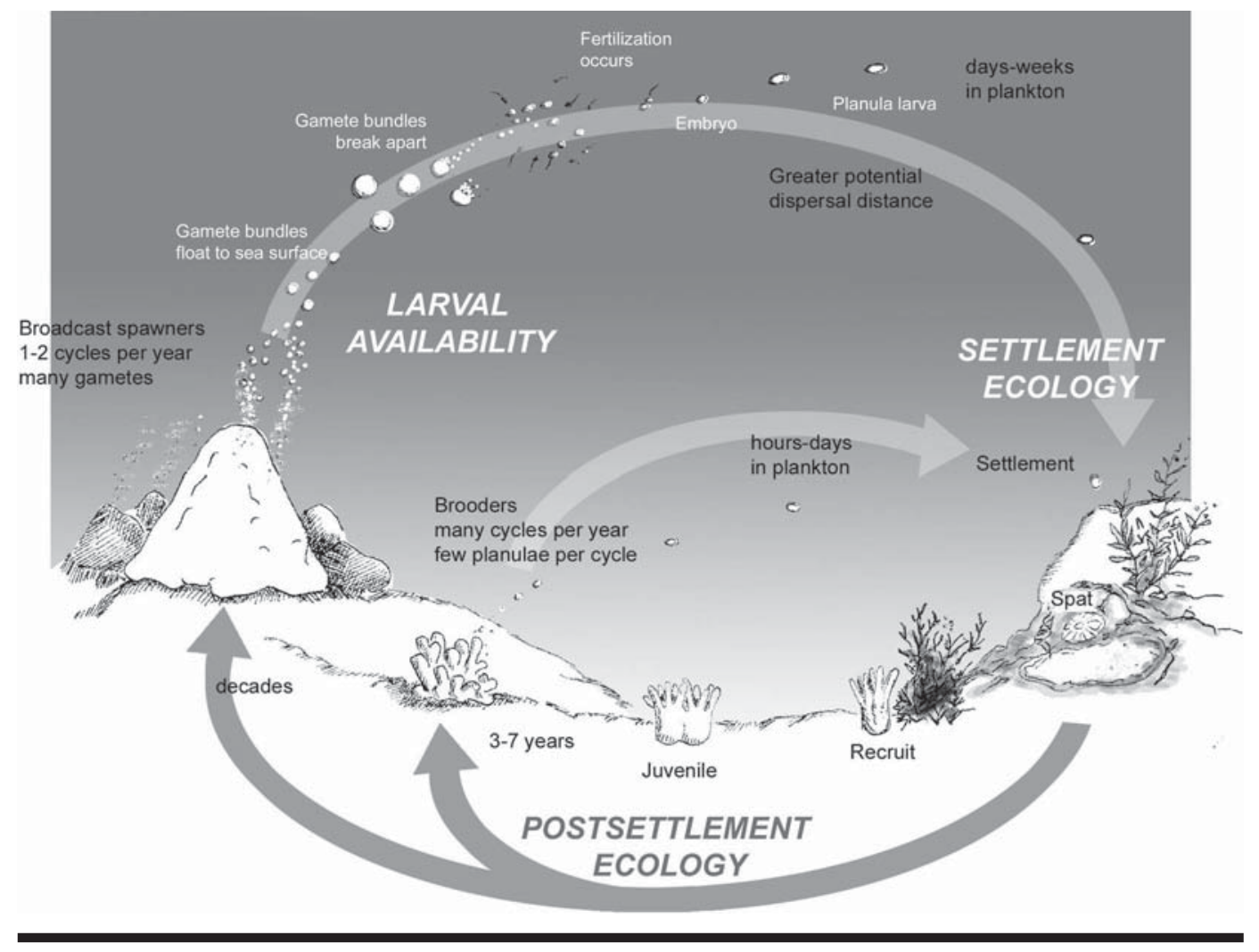

FIGURE 1. Three sequential phases necessary for successful coral recruitment starting with larval availability, progressing to settlement ecology, and ending with post-settlement ecology. (Drawn by Mark Vermeij.) 

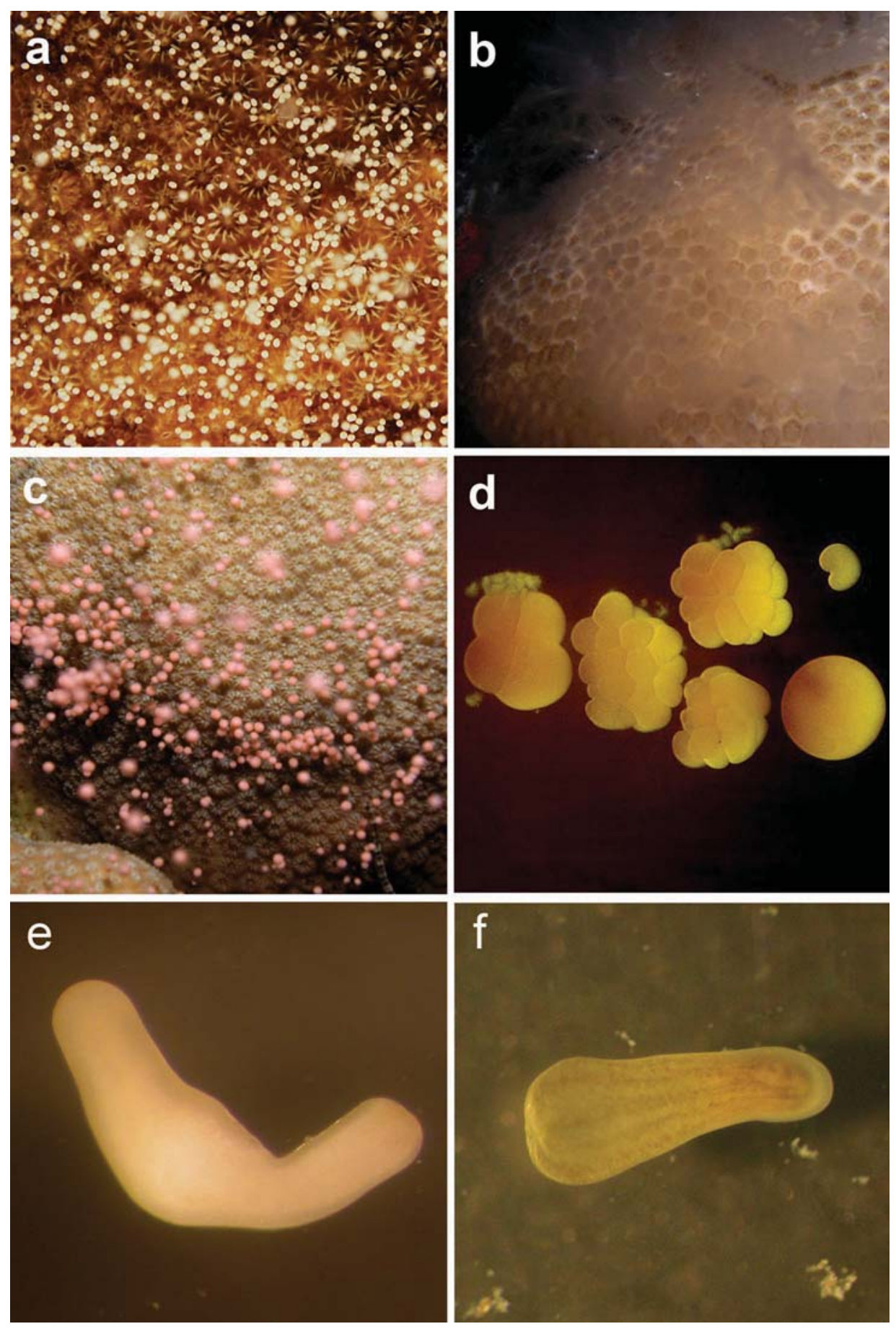

FIGURE 2. Different modes of reproduction influence larval supply in coral species. a, Female Stephanocoenia intersepta, a gonochoric spawner, releases eggs. b, A male S. intersepta releases sperm. c, The hermaphrodite Montastraea faveolata releases eggs and sperm as bundles that float to the surface, where they break apart for fertilization. d, For Acropora palmata (and other spawners), fertilization of coral eggs occurs in the water column. e, A larva of Acropora palmata completes development in the water column. f, In contrast, a larva of Porites astreoides (a brooder) is fully developed when it is released from its parent and contains zooxanthellae. (Photographs a, b, by Mark Vermeij; c, e, f, by Raphael Ritson-Williams; d, by Nicole Fogarty.) 
A minority of reef-building coral species worldwide are brooders, but brooding is the dominant reproductive mode found in the Caribbean Sea (Szmant, 1986; Richmond and Hunter, 1990; Smith, 1992). Broadcast spawning is a more common reproductive mode in coral species, and in Australia more than 100 coral species may spawn on a single night (Harrison et al., 1984; Willis et al., 1985; Babcock and Heyward, 1986). Species representing these modes differ in colony size, gametic cycles, larval competency, dispersal distance, and zooxanthellae transmission (Richmond and Hunter, 1990). Brooders are typically smaller than spawning corals and have multiple planulating cycles per year, as opposed to one or two cycles in broadcast spawners (Szmant, 1986).

\section{FECUNDITY}

Reproductive mode determines the frequency of larval release; however, both abiotic and biotic factors can influence the amount of gametes produced in corals. The production of gametes is only possible when a coral has reached an age, and perhaps more importantly a size, capable of reproduction (Hughes, 1984; Szmant, 1986). It is difficult to measure the impact of stressors on gamete production because it is naturally variable both temporally and between individuals within a species (Chorneskey and Peters, 1987). As coral cover declines in both the Caribbean Sea and the Pacific Ocean (Gardner et al., 2003; Bruno and Selig, 2007) there are fewer and often smaller adult colonies. This change could reduce coral fecundity because small body size reduces gamete production (Szmant, 1986) and low population densities reduce fertilization success (see Fertilization section, below). Even with relatively high adult coral densities the fecundity of individual colonies can be decreased by many stressors before and during gametogenesis.

Coral bleaching has been observed to stop gametogenesis (Szmant and Gassman, 1990), reduce the number of gametes produced (Fine et al., 2001), and decrease fertilization rates in Acropora corals (Omori et al., 2001). Nutrients added to the water column decreased the number of successfully developed embryos that were formed in the corals Acropora longicyathus and A. aspera (Koop et al., 2001). Changes in salinity and sedimentation can also reduce gamete production and fertilization success in corals (Richmond, 1993a, 1993b). Guzman et al. (1994) suggested that the increase in injury levels and slower growth in corals exposed to an oil spill further reduced gamete size, viability, and fecundity. The presence of macroalgae adjacent to coral colonies can decrease fecundity (includ- ing the number and size of eggs) in the corals Montastraea annularis and Montipora digitata (Hughes et al., 2007; Foster et al., 2008). Impacts on fecundity are perhaps best summarized by Rinkevich and Loya (1987), who suggested that because reproductive activity involves such high energy expenditure, any stress that diminishes energy reserves will have an effect on adult fecundity.

\section{FERTILIZATION ECOLOGY}

Because broadcast spawners only have one or two planulating cycles a year, it is imperative that fertilization be successful. In any broadcast species, fertilization success is highly variable and largely depends on the synchronization of gamete release, gamete compatibility (Palumbi, 1994; Levitan et al., 2004), gamete age (Oliver and Babcock, 1992; Levitan et al., 2004), and abundance of spawning adults (Levitan et al., 1992, 2004). However, the health of the spawning colony and environmental conditions during the spawning event also affect fertilization success (Richmond, 1997; Humphrey et al., 2008).

During multispecies spawning events, synchronized gamete release and species-specific gamete recognition are critical for fertilization success and reducing the probability of interspecific fertilization (hybridization), which may result in reduced offspring fitness (Mayr, 1963); however, Willis et al. (2006) suggest a role for hybridization in range expansion and adaptation to a changing environment. Species with overlapping spawning times typically display low interspecific fertilization success in laboratory crosses (Willis et al., 1997; Hatta et al., 1999; Levitan et al., 2004). Interspecific fertilization success is usually higher among morphologically similar species, suggesting they are more closely related or possibly the same species (Willis et al., 1997; Hatta et al., 1999; Wolstenholme, 2004), but interspecific fertilization can also occur between Acropora species that have very different branching morphologies (Hatta et al., 1999). Fertilization success during a mass spawning event could be the result of sperm attractant molecules produced by coral eggs (Coll et al., 1994; Babcock, 1995) but could also be regulated by gamete recognition proteins, such as those that ensure species-specific fertilization in spawning sea urchins (Zigler et al., 2005).

If coral colonies spawn asynchronously or encountered gametes are not compatible, eggs may go unfertilized for extended periods of time or sperm may lose its viability. The effect of age on gamete viability and fertilization success differs among coral species; Platygyra sinensis showed reduced fertilization after three hours (Oliver and 
Babcock, 1992), but in Acropora spp. reduced fertilization success occurred after seven to eight hours (Willis et al., 1997; Omori et al., 2001). With increasing gamete age, fertilization success is reduced in conspecific crosses, but aging effects on gamete viability differ between sperm and eggs. Montastraea spp. sperm lose viability after two hours but eggs stay viable for more than three hours (Levitan et al., 2004). Another consequence of gamete aging is an increase in the likelihood of interspecific fertilization. Hybridization rates between Montastraea faveolata eggs and $M$. annularis and M. franksi sperm increased when eggs had aged at least 75 minutes (Levitan et al., 2004). Increased interspecific fertilization may be caused by a breakdown in gamete recognition proteins, but the specific mechanisms remain to be determined.

The density of spawning individuals plays a critical role in fertilization success. If reproductive individual densities are too low, fertilization success will be limited (also referred to as the allee effect) (Levitan and McGovern, 2005). Coma and Lasker (1997) found that fertilization success in gorgonians was influenced by the density of gametes, which was determined by nearest neighbor distances (approximately $10 \mathrm{~m}$ ), synchronous gamete release, or hydrodynamic processes. These factors probably influence scleractinian fertilization success; however, it is difficult to directly measure species-specific sperm concentrations in situ because a number of coral species spawn synchronously. Field studies examining sperm concentrations have used either of two methods: (1) measuring the percent of fertilized eggs collected at different times and locations on the reef or (2) determining the fertilization potential of collected surface water samples by adding them to unfertilized eggs and recording the proportion of eggs fertilized (Oliver and Babcock, 1992; Levitan et al., 2004). When lower production or dilution resulted in locally lower than normal sperm concentrations, fertilization success was reduced (Oliver and Babcock, 1992; Willis et al., 1997; Omori et al., 2001; Levitan et al., 2004). These studies showed peak fertilization potential during or shortly after coral species spawn (Oliver and Babcock, 1992; Levitan et al., 2004). Hence, synchronized gamete release is a mechanism for the high gamete density needed to ensure fertilization success.

High gamete concentration brings with it a potential risk as well; as sperm densities increase so does the probability of polyspermy, whereby eggs become fertilized by more than one sperm cell, which results in lowered fertilization rates and developmental failure (Styan, 1998; Tomaiuolo et al., 2007). Reduced fertilization success at high sperm concentrations has been described for several coral species (Oliver and Babcock, 1992; Willis et al., 1997; Levitan et al., 2004), suggesting polyspermic fertilization can occur in scleractinian corals. These findings suggest a trade-off between spawning synchronously (i.e., high gamete density) with other conspecifics to increase fertilization and the potential risk of polyspermy. Polyspermy may therefore act as a negative density-dependent mechanism. Despite the evidence for polyspermy in coral laboratory crosses, field fertilization rates never reached $100 \%$ during mass spawning events (97\% maximum; Levitan et al., 2004), suggesting that polyspermic conditions are unlikely to occur in nature. In light of recent decreases in adult coral populations, reduced adult density and gamete aging are perhaps the greatest threats to larval production.

\section{Larval Transport: Dispersal and ConNectivity}

After gamete fertilization, developing planula larvae transport typically away from reproductive populations (called "dispersal") and to reefs where they recruit (called “connectivity") (Levin, 2006). The density of planulae arriving to a reef determines recruitment strength. Larval survival during dispersal varies by means of a combination of hydrodynamic processes, larval energetics, predation pressure (Fabricius and Metzner, 2004), and water quality (Richmond et al., 2007).

Reproductive modes can provide insight into dispersal potential, even though the planktonic duration of coral species can be highly variable and remains undocumented for the majority of scleractinian species. For example, brooders generally settle within hours after release (Carlon and Olson, 1993), whereas broadcast spawners such as Acropora spp., Goniastrea spp., Platygyra spp., and Montastraea spp. have planktonic period of 4 to 7 days before they are competent to settle and metamorphose (Babcock and Heyward, 1986; Szmant, 1986). Larvae of the broadcast spawners Acropora muricata and A. valida settled within 9 to 10 days (Nozawa and Harrison, 2008), but larvae of the spawning corals Platygyra daedalea and Goniastrea favulus can settle between 2 and 3 days after fertilization, which is sooner than some brooding corals, suggesting that dispersal of these species might be of shorter duration than has been assumed from survival estimates (Miller and Mundy, 2003). In the absence of settlement substrate, a small percentage of Acropora latistella, Favia pallida, Pectinia paeonia, Goniastrea aspera, and Montastraea magnistellata larvae survived for 195 to 244 days in the water column (Graham et al., 2008). Planulae larvae can probably survive drifting in the plankton for long durations until they encounter suitable settlement substrate; 
however, the length of the planktonic period will partially depend on whether the larvae have acquired zooxanthellae, which give them additional energy reserves, from the parent colony (Richmond, 1987).

The frequency of recruitment as a function of distance from a reproductive source population is called a "dispersal kernel” (Steneck, 2006). For most planktonic larvae it was assumed that relatively long larval survival potential in combination with oceanographic transport would generally prevent settlement close to a reproductive source (Cowen et al., 2006). Recent reviews suggest that even though many marine invertebrate larvae have the potential (energy reserves) for long-distance dispersal, they often settle locally because of a combination of oceanographic conditions, larval behavior, and increasing mortality associated with planktonic conditions (Cowen et al., 2000; Strathmann et al., 2002; Levin, 2006). The shape of most dispersal kernels is now thought to be skewed toward the reproductive source, that is, increased rates of local recruitment (Figure 3; Steneck, 2006). Most dispersal and connectivity research to date has focused on fishes;

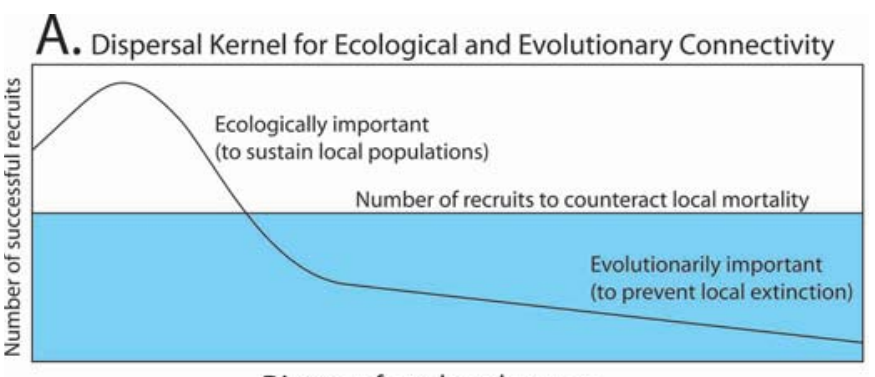

Distance from larval source

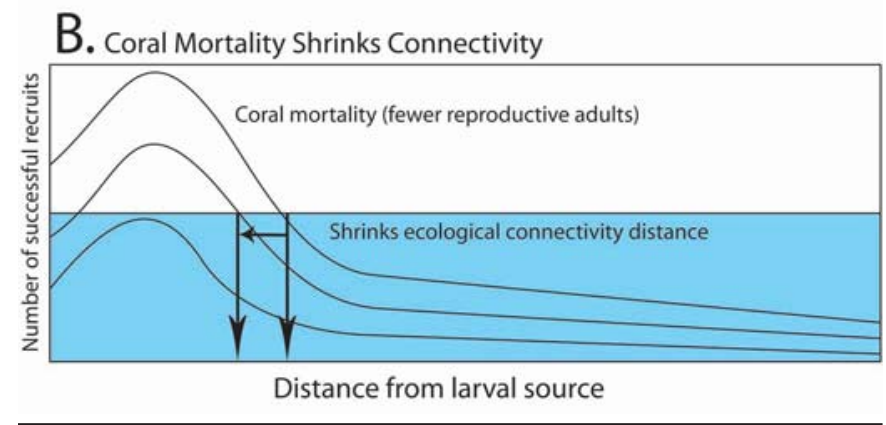

FIGURE 3. Dispersal kernels determine potential connectivity distance between reproductive populations and offspring. A, Distinction between ecologically important recruitment necessary to balance against local mortality and evolutionarily important recruitment to balance against local extinction. B, Shrinking dispersal kernels resulting from adult coral mortality. (After Steneck, 2006.) however, one study measured ecological connectivity of coral larvae via a field experiment conducted around the isolated Helix Reef in Australia (Sammarco and Andrews, 1988). They reported that $70 \%$ of coral recruitment occurred within $300 \mathrm{~m}$ of the larval source and that rates of recruitment declined with distance downstream from the reef (Sammarco and Andrews, 1988). Further, as expected, broadcasters dispersed farther than did species of brooding corals, but the estimated ecologically relevant dispersal kernel for both species was remarkably local. A recent review discusses the limited dispersal kernel of coral planulae (Steneck, 2006); however, there is little experimental evidence for the mechanisms that determine coral ecological connectivity.

Recruitment rates must equal or exceed rates of adult mortality to sustain a local population. Most dispersal kernels show high rates of recruitment near the reproductive source, with recruitment decreasing as distance increases (Figure 3). Although that tail is important for gene flow, that low density of settlement is not sufficient to sustain populations. That is, the ecologically relevant portion of a dispersal kernel reflects the sustained rate of recruitment necessary to compensate for rates of mortality. The critical level of settlement to sustain populations (i.e., horizontal line above each shaded half of Figure 3 ) is not known; however, colonization rates of the introduced orange cup coral Tubastraea coccina can provide some real-world insights into the scale of ecological and evolutionary connectivity. This brooding species was first introduced to the Netherlands Antilles in 1943 and then spread from island to island through the Caribbean, taking 50 years to reach the Bahamas and 60 years to reach Florida (Fenner and Banks, 2004). Once in a region, local populations grew rapidly. This finding is consistent with the concept that the biogeographic spread results from the evolutionarily important "long tail" of the dispersal kernel, whereas the ecologically and demographically significant portion of the dispersal kernel controlling local colonization is much smaller and more local (Figure 3A). Observations of the spread of $T$. coccina are conservative because some of the spread of this species probably resulted from colonized ships moving among the regions (Fenner and Banks, 2004).

Ecological connectivity necessary to sustain populations against chronic mortality is much more difficult to measure than is evolutionary connectivity. Evolutionary or genetic connectivity can be directly measured using a variety of molecular genetic techniques (reviewed in Hellberg, 2007). In Japan, gene flow between islands 30 to $150 \mathrm{~km}$ apart was determined to be consistently higher for the spawner Acropora tenuis than for the brooding 
species Stylophora pistillata, but both coral species had unique genotypes across islands separated by $500 \mathrm{~km}(\mathrm{Ni}-$ shikawa et al., 2003). In the Caribbean, a genetic break was detected for Acropora palmata, roughly dividing populations from the Greater Antilles and western Caribbean from populations in the Lesser Antilles and the southern and eastern Caribbean (Baums et al., 2005). On the relatively contiguous Great Barrier Reef (GBR), high rates of genetic connectivity were observed for both brooders and spawners. For example, gene flow was detected in all the spawners and three of the five brooders despite being separated by 500 to $1,200 \mathrm{~km}$ (Ayre and Hughes, 2000). However, the same species of corals were genetically distinct on Lord Howe Island, which is separated from the GBR by $700 \mathrm{~km}$ (Ayre and Hughes, 2004). This observation suggests that coral larvae can use islands within the evolutionarily important tail of the dispersal kernel as "stepping stones" to maintain genetic connectivity between distant reefs separated by long distances (Steneck, 2006).

Although dispersal kernels are useful for visualizing how larval availability declines with distance from a source, their ecological effect can be variable. For example, without changing the shape of the kernel but reducing the number of recruits as a consequence of reduced reproductive output following an adult mortality event (Figure 3B), the range of both the ecological and evolutionary parts of the kernel can shrink. If this happens, connectivity among distant reefs could sever, making recovery following an acute disturbance difficult or impossible.

\section{SETTLEMENT ECOLOGY}

As local and global threats continue to decrease coral cover, it is likely that fewer coral larvae will be supplied to reefs that may or may not have appropriate settlement habitat. For corals, the transitional stage from planktonic planula larvae to sessile benthic juveniles involves a twostep process of settlement and metamorphosis. Settlement is the behavioral response of a larva when it stops dispersal and selects substrate for recruitment. Metamorphosis includes the subsequent morphological and physiological changes that pelagic larvae undergo to become benthic juveniles. Settlement of coral larvae can be influenced by habitat qualities that facilitate or inhibit settlement and metamorphosis of larvae supplied to a reef (Figure 4). Larval settlement behavior can be determined by the conditions the larvae experienced in the plankton or by the presence of positive or negative cues on the benthos or in the water overlying the reef.

\section{Larval Condition upon Arrival}

As coral larvae disperse in the plankton they are exposed to water quality conditions that may affect larval health, behavior, survival, and settlement success (Vermeij et al., 2006). Experiences during early life stages (i.e., depleted energy reserves, nutritional stress, environmental stressors, and pollutant exposure) have latent effects on later life stages in numerous marine larvae across different phyla (reviewed in Pechenik, 2006). Even short-term exposure to stressors or a slight delay in metamorphosis can reduce fitness in juveniles and adults (i.e., decrease growth rate, lower competitive ability, reduce survival, and decrease fecundity) (Pechenik, 2006). Although the mechanisms through which latent effects are mediated are not known, it is suspected that transcriptional or translational processes or direct DNA or key enzyme damage are responsible (Pechenik et al., 1998; Heintz et al., 2000; Pechenik, 2006). As very few studies have tested latent effects in coral larvae, we describe some of the patterns found in other marine organisms to highlight how pre-settlement stress might impact post-settlement coral growth and survival.

Marine invertebrate larvae often rely on external cues to trigger metamorphosis. Without these cues, the larval period can be prolonged (reviewed in Pechenik, 1990), and post-settlement fitness may be reduced (Pechenik, 2006). For some invertebrates, including abalones, tunicates, and bryozoans, delayed metamorphosis slowed post-metamorphic development (Wendt, 1998; Roberts and Lapworth, 2001; Marshall et al., 2003). Depleted energy resources during the larval stage may also be an important contributor to post-settlement growth and survival. Bennett and Marshall (2005) found that depleted energy reserves caused by increased activity in larvae of the ascidian Diplosoma listerianum were more costly energetically than extending the larval period or completing metamorphosis. Food limitation during the larval period can reduce size, total organic content, energy reserves of metamorphosed animals, juvenile growth rates, and survival (Miller, 1993; Pechenik, 2002; Thiyagarajan et al., 2003; Chiu et al., 2007, 2008).

Water quality conditions can directly reduce coral larval survival and settlement but also may cause latent effects for new recruits. Salinity reductions during presettlement periods can reduce post-metamorphic growth rates and survival for various marine invertebrates (Pechenik et al., 2001; Thiyagarajan et al., 2008). Vermeij et al. (2006) tested salinity stress on Montastraea faveolata larvae and how that influenced subsequent post-settlement 

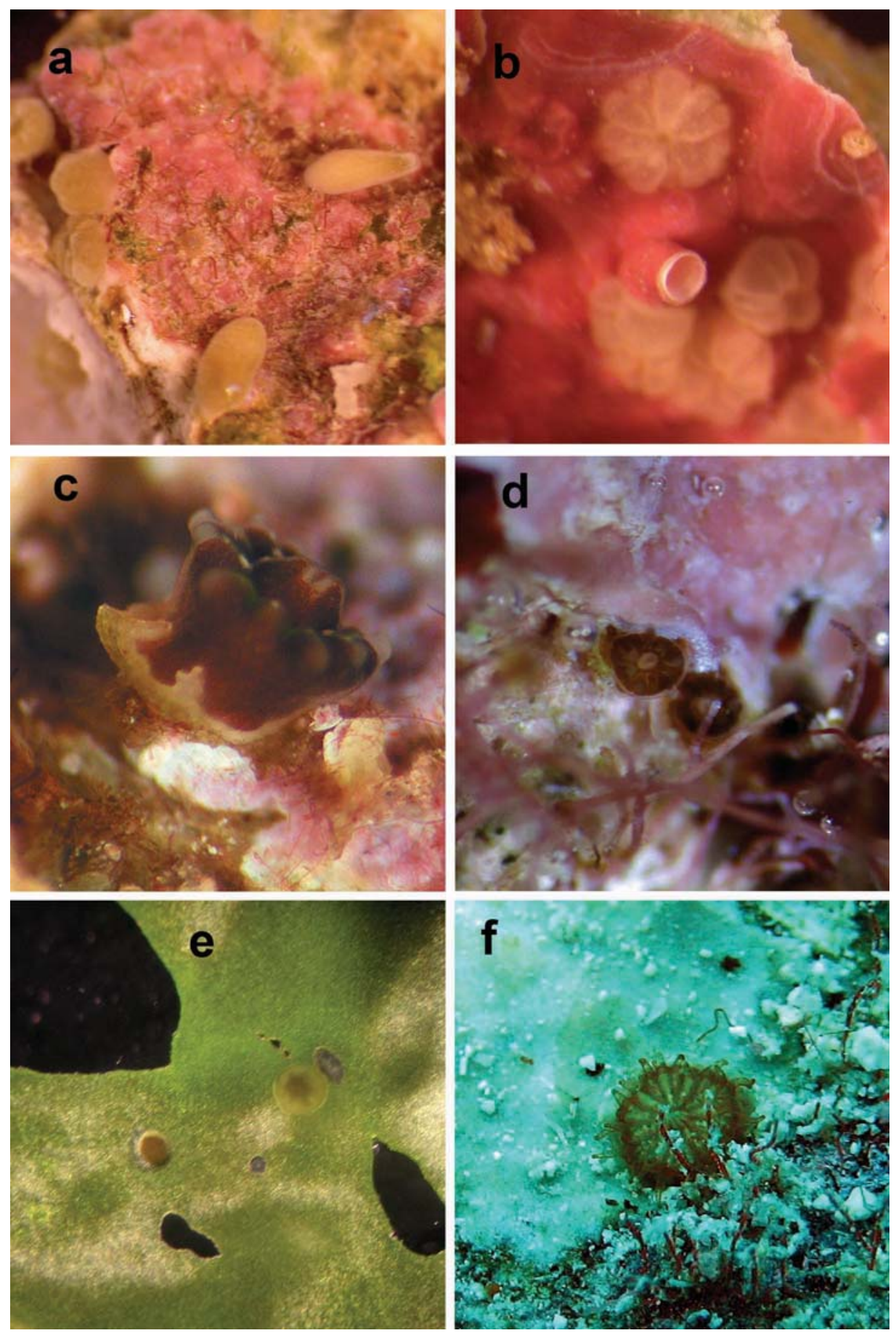

FIGURE 4. Coral larval substrate selection is critical to post-settlement survival. a, Favia fragum larvae explore the benthos for a suitable settlement site; some larvae have already attached and are beginning to metamorphose. b, Acropora cervicornis settlers are attached to Titanoderma prototypum and have metamorphosed. c, A new recruit of Montastraea faveolata has settled on coralline algae, which has started to slough its outer layer of tissue, knocking the coral recruit off the substrate. $\mathrm{d}$, Montastraea faveolata recruits are being overgrown by a coralline alga. e, Montipora capitata larvae have settled on Ulva sp., an ephemeral substrate. f, A Siderastrea radians recruit has settled in a high-sedimentation environment. (Photographs a, b, by Raphael Ritson-Williams; c, d, by Nicole Fogarty; e, f, by Mark Vermeij.) 
performance. Lower than normal seawater salinity caused increased pre- and post-settlement mortality and increased the mobility of coral planulae. It was suggested that the increased activity of the larvae in the lower salinities was an attempt to escape the unfavorable conditions. With increased activity, energy reserves were depleted, which was suggested to be the cause of pre-settlement mortality, smaller post-settlement size, and lower post-settlement survival. Planulae in the lower-salinity treatments settled on a greater range of substrate types. This study emphasized the importance of planktonic conditions on the performance of settling coral larvae, which could then influence post-settlement ecology.

\section{Larval Behavior in OVerlying Water}

Coral larvae possess a wide array of behaviors that allow them to enhance the likelihood of successful settlement, including, but not limited to, sensitivity to light (Lewis, 1974; Mundy and Babcock, 1998), depth (Carlon, 2001, 2002; Baird et al., 2003; Suzuki et al., 2008), and chemical cues (Morse et al., 1994). One field study showed that multiple behavioral choices determined the larval settlement site of the Caribbean brooder Agaricia bumilis (Raimondi and Morse, 2000). The larvae swam down when restricted to 3 and $8 \mathrm{~m}$ but swam toward the surface when restricted to $25 \mathrm{~m}$. In further field experiments, larvae settled in response to the coralline alga $\mathrm{Hy}$ drolithon boergesenii but would only settle directly on the coralline alga when it was on the underside of a settlement tile. This study showed that coral larvae are capable of complex behaviors, which are determined to some extent by their ability to detect and discriminate between positive and negative settlement cues in their habitat.

\section{Positive Settlement Cues}

Many marine invertebrate larvae use chemical cues to determine the appropriate habitat for settlement (Pawlik, 1992; Hadfield and Paul, 2001). Chemical cues are implicated for both settlement and metamorphosis of corals and may be released by conspecifics and other organisms that indicate appropriate habitat for survival and growth. Research in the Caribbean showed that a membrane-bound carbohydrate complex from the coralline red alga Hydrolithon boergesenii induced settlement and metamorphosis in the brooded larvae of Agaricia humilis (Morse and Morse, 1991; Morse et al., 1994). It was suggested that many corals require an algal cue for the induction of settlement, indicating a common chemosensory mechanism for settlement and metamorphosis among coral larvae (Morse et al., 1996).
Both the larvae of Acropora millepora, a common Indo-Pacific coral species, and coral larvae collected from natural slicks after mass spawning events used coralline algae for settlement and metamorphosis (Heyward and Negri, 1999). Four species of crustose coralline algae, one non-coralline crustose alga, two branching coralline algae, and the skeleton of the massive coral Goniastrea retiformis induced metamorphosis. Chemical extracts from both the crustose red alga Peyssonnelia sp. and the coral skeleton were highly active, inducing up to $80 \%$ larval metamorphosis. Coral larvae can also distinguish among species of coralline algae. The Australian spawning coral Acropora tenuis had different rates of settlement in response to different species of coralline algae (Harrington et al., 2004). Settlement choice resulted in higher rates of post-settlement survival on the preferred coralline algae, illustrating the recruitment consequences of larval selectivity. Chemical cues appeared to be involved in this selective behavior, because methanol extracts of the coralline red algae Titanoderma prototypum and Hydrolithon reinboldii both induced metamorphosis of A. tenuis.

Comparative studies have revealed that settlement and metamorphosis in response to crustose coralline algae is not an obligate trait of all coral species. Two brooding Australian corals were compared for their settlement selectivity (Baird and Morse, 2004). Acropora palifera larvae only metamorphosed in the presence of coralline red algae, but Stylophora pistillata larvae showed some metamorphosis in unfiltered seawater and also metamorphosed onto glass coverslips. A study in Guam found that larvae of the spawning species Goniastrea retiformis preferred substrate covered with crustose coralline algae (CCA), but the reef-flat brooding coral Stylaraea punctata preferred biofilmed rubble (Golbuu and Richmond, 2007).

Coralline algae have been identified as a positive settlement cue for some corals, but it is unclear if the biofilms present on these algae or the algae themselves are responsible for the observed settlement behavior (Johnson et al., 1991; Webster et al., 2004). Biofilms were isolated from the coralline alga Hydrolithon onkodes, and one strain of bacteria alone was enough to induce settlement and metamorphosis of Acropora millepora larvae (Negri et al., 2001). When H. onkodes was sterilized in an autoclave and treated with antibiotics, it still induced significantly more settlement and metamorphosis than seawater or terracotta tiles. Additionally, coral larvae can distinguish between tiles conditioned at different depths, which could be related to depth-related differences in bacterial community composition of biofilms that formed on tiles (Webster et al., 2004). Whether the coralline algae or its biofilm is producing the inductive compound(s) may depend on the 
coral and the coralline algae species tested. The specificity of bacterial communities to different coralline algal species has rarely been investigated (Johnson et al., 1991). With the recent development of more refined genetic techniques it is possible to compare different microbial communities, which might enable the identification of the microbe(s) that can induce coral larval settlement and metamorphosis.

\section{Negative Settlement Cues}

Water quality and substrate conditions impact fertilization rates and also may inhibit some coral larvae from normal settlement and metamorphosis. Low coral recruitment is commonly documented in the field, yet surprisingly few studies have experimentally tested which substrate characteristics might deter coral larval settlement. Coral larval survival and settlement can be reduced by many environmental stresses, such as elevated temperatures (Edmunds et al., 2001), variation in salinity (Vermeij et al., 2006), sedimentation (Hodgson, 1990; Gilmour, 1999), and UVB radiation (Kuffner, 2001; Gleason et al., 2006). Survival and settlement are reasonable ecological metrics for the effects of stress, but an important gap in our knowledge is how sublethal stress influences larval behavior and postsettlement health and success (Downs et al., 2005). New techniques including cellular biomarkers and differential gene expression using microarrays should provide important techniques to measure sublethal stress in coral larvae.

Water quality conditions that are known to impact adult corals also have dramatic effects on larval supply and settlement. Of the physical conditions that negatively influence larval settlement, elevated temperature has received the most attention and has the potential to increase in frequency and duration as ocean temperatures continue to warm. Larvae of the Caribbean brooding coral Porites astreoides were killed and had low densities of zooxanthellae when exposed to elevated temperatures for 24 hours (Edmunds et al., 2001, 2005). High temperatures $\left(36^{\circ} \mathrm{C}\right)$ killed Acropora muricata larvae within 40 hours (Baird et al., 2006), and temperatures of $32^{\circ} \mathrm{C}$ killed Diploria strigosa larvae and reduced their settlement (Bassim and Sammarco, 2003). However, at elevated temperatures $\left(29^{\circ} \mathrm{C}\right)$ larvae of Stylophora pistillata had the same settlement as at $25^{\circ} \mathrm{C}$ (Putman et al., 2008), and more larvae settled on the CCA in $25^{\circ} \mathrm{C}$ than in $23^{\circ} \mathrm{C}$. Many of these studies used different experimental conditions, making it difficult to compare the effects of temperature on different species of coral larvae. Temperature is one stress that is relatively well studied, but more research is necessary to understand other physical stressors, such as ocean acidifi- cation (Albright et al., 2008), that will affect coral larvae in the future.

Larval interactions with the biological inhabitants of reef communities can also reduce larval settlement. Algal turfs, macroalgae, and benthic cyanobacteria can negatively impact the settlement of coral larvae (Kuffner and Paul, 2004; Birrell et al., 2005; Kuffner et al., 2006; Birrell et al., 2008a). In the Florida Keys, two brown algae, Dictyota pulchella and Lobophora variegata, reduced the total number of Porites astreoides settlers (Kuffner et al., 2006). In the Philippines, the algae Sargassum polycystum and Laurencia papillosa decreased larval settlement of Pocilloproa damicornis, but water conditioned with these algae increased settlement over the seawater controls (Maypa and Raymundo, 2004). In Australia, water conditioned with the foliose brown alga Padina sp. reduced larval settlement of Acropora millepora; however, water conditioned with the brown alga Lobophora variegata increased settlement (Birrell et al., 2008a). The cyanobacterium Lyngbya majuscula reduced the survivorship of Acropora surculosa larvae and settlement and metamorphosis of Pocillopora damicornis in studies conducted on Guam (Kuffner and Paul, 2004), and in Florida, the cyanobacterium Lyngbya polychroa caused Porites astreoides to avoid settling adjacent to it on settlement tiles (Kuffner et al., 2006). Some macroalgae and cyanobacteria can act as settlement inhibitors for coral larvae, but this was not true for all the algae tested. A surprising contrast was observed for Favia fragum larvae, which had high rates of settlement and metamorphosis onto live Halimeda opuntia when offered with coral rubble (Nugues and Szmant, 2006). Coral larvae of Montipora capitata were observed to settle onto Ulva sp. (Figure 4e; Vermeij et al., 2009). Why these larvae would settle directly onto blades of algae is unclear as this substrate is ephemeral, thus probably increasing post-settlement mortality. Little research has been done on the mechanisms that algae use to inhibit settlement, but algal qualities such as natural products, shading and abrasion, serving as vectors of bacteria, and releasing dissolved organic matter may contribute to the negative impacts of algae on larval settlement.

Competition from other members of coral reef communities also influences larval behavior. Tissue of the scleractinian coral Goniopora tenuidens suspended in seawater inhibited metamorphosis of Pocillopora damicornis larvae and reduced the growth of new recruits over seven days (Fearon and Cameron, 1996). The tissue from Goniopora tenuidens also caused increased mortality of larvae from P. damicornis, Platygyra daedalea, Fungia fungites, and Oxypora lacera. Increased research on the types of benthic 
organisms and the mechanisms they use for competition with coral larvae is an important area for further study. An integrated approach to larval stress, physiology, and the physical and biological characteristics of settlement substrata will reveal the impact of benthic organisms on coral larval behavior, settlement, and post-settlement survival. Determining what benthic habitat characteristics are necessary for increased settlement will be a critical step for managing reef habitats for increased coral recruitment.

\section{POST-SETTLEMENT ECOLOGY}

Corals, and most benthic marine organisms, suffer high rates of mortality soon after settlement because they are small and vulnerable. Post-settlement processes from the time corals settle (i.e., attach to the benthos) to recruitment (i.e., survive to some later phase) determines much of coral demography (Vermeij and Sandin, 2008). This concept is consistent with the tenet of clonal population biology that states as clonal organisms grow the probability of their death declines but the probability of injury increases (Hughes and Jackson, 1985). Thus, the two rates of early post-settlement mortality and growth can strongly influence the local abundance of corals.

\section{Post-Settlement Mortality}

Coral recruits can die from a myriad of causes including chronic disturbances such as competition and predation and pulse disturbances such as bleaching and disease. However, the chronic disturbances probably drive most post-settlement mortality and thus are serious impediments to reef recovery. Caribbean reefs are a case in point, with incidences of recovery much lower than Indo-Pacific reefs as a result of setbacks from chronic disturbances (Connell et al., 1997).

Algae, encrusting invertebrates, and sediment have all been shown to have deleterious effects on newly settled corals (Figure 5; Rylaarsdam, 1983). Settling corals, with limited stores of energy to invest in competitive interactions, are particularly vulnerable when faced with a well-developed benthic community structure and limited space (Jackson and Buss, 1975; Sebens, 1982; Connell et al., 1997). However, the mechanisms, or causes, of reduced growth and mortality of newly settled larvae, recruits, and juveniles have, for the most part, only recently been investigated.

Encrusting invertebrates (particularly sponges) can be especially inhospitable for newly settled corals. In cryptic habitats, newly settled corals are likely to lose out by overgrowth of fast-growing heterotrophic groups such as sponges, bryozoans, and bivalves (Vermeij, 2005). Aerts and van Soest (1997) determined the impact of sponges on coral survival to be greatly species specific. Physical, chemical, and biological properties of benthic invertebrates may inhibit coral growth and survival. Some studies used chemical extracts of sponges (Sullivan et al., 1983; Pawlik et al., 2007) to show that allelopathy can negatively impact adult corals. Coral recruits are even more susceptible to stress, yet surprisingly few studies have examined secondary metabolites for their impact on the early life history stages of corals. A field study by Maida et al. (1995) suggested that allelopathy reduced recruitment of corals adjacent to the octocorals Sinularia flexibilis and Sarcophyton glaucum, and both the live octocorals and settlement plates with dichloromethane extracts of $S$. flexibilis inhibited coral settlement and survival. More long-term, small spatial scale (millimeters to centimeters) studies are needed to determine the effect of benthic invertebrates on post-settlement survival (Edmunds et al., 2004; Vermeij, 2006).

Areas of high algal biomass are known to be poor nursery habitats for settling corals (Birkeland, 1977; Bak and Engel, 1979; Harriott, 1983; Birrell et al., 2008b; Vermeij and Sandin, 2008; Vermeij et al., 2009). There are several mechanisms by which algae may be deleterious to corals. Algae may interfere with larval settlement by simply preempting available settlement space (Mumby et al., 2006; Box and Mumby, 2007). At least one species of turf algae alone (without sediment) has reduced settlement of corals in laboratory experiments (Birrell et al., 2005). More direct physical interactions including algal shading, abrasion, or basal encroachment can result in reduced coral growth or increased mortality (Lirman, 2001; McCook et al., 2001). Shading by the encrusting brown alga Lobophora variegata over six months caused a $50 \%$ increase in morality of juvenile Agaricia agaricites (less than $20 \mathrm{~mm}$ diameter), and the mere presence of $L$. variegata around the coral reduced colony growth by $60 \%$ (Box and Mumby, 2007). However, shading by Dictyota pulchella resulted in no direct mortality but caused a $99 \%$ decrease in coral growth. Other studies have determined that Lobophora variegata (in the absence of grazing) is a superior competitor to Caribbean corals, including A. agaricites, A. lamarcki, Meandrina meandrites, Mycetophyllia aliciae, and Stephanocoenia intersepta, and to at least one species of Pacific coral, Porites cylindrica (De Ruyter van Steveninck et al., 1988; Jompa and McCook, 2003). Thus, it is likely that community phase shifts to high algal biomass decrease recruitment by reducing larval settlement and post-settlement survival (Hughes and Tanner, 2000; Kuffner et al., 2006). 

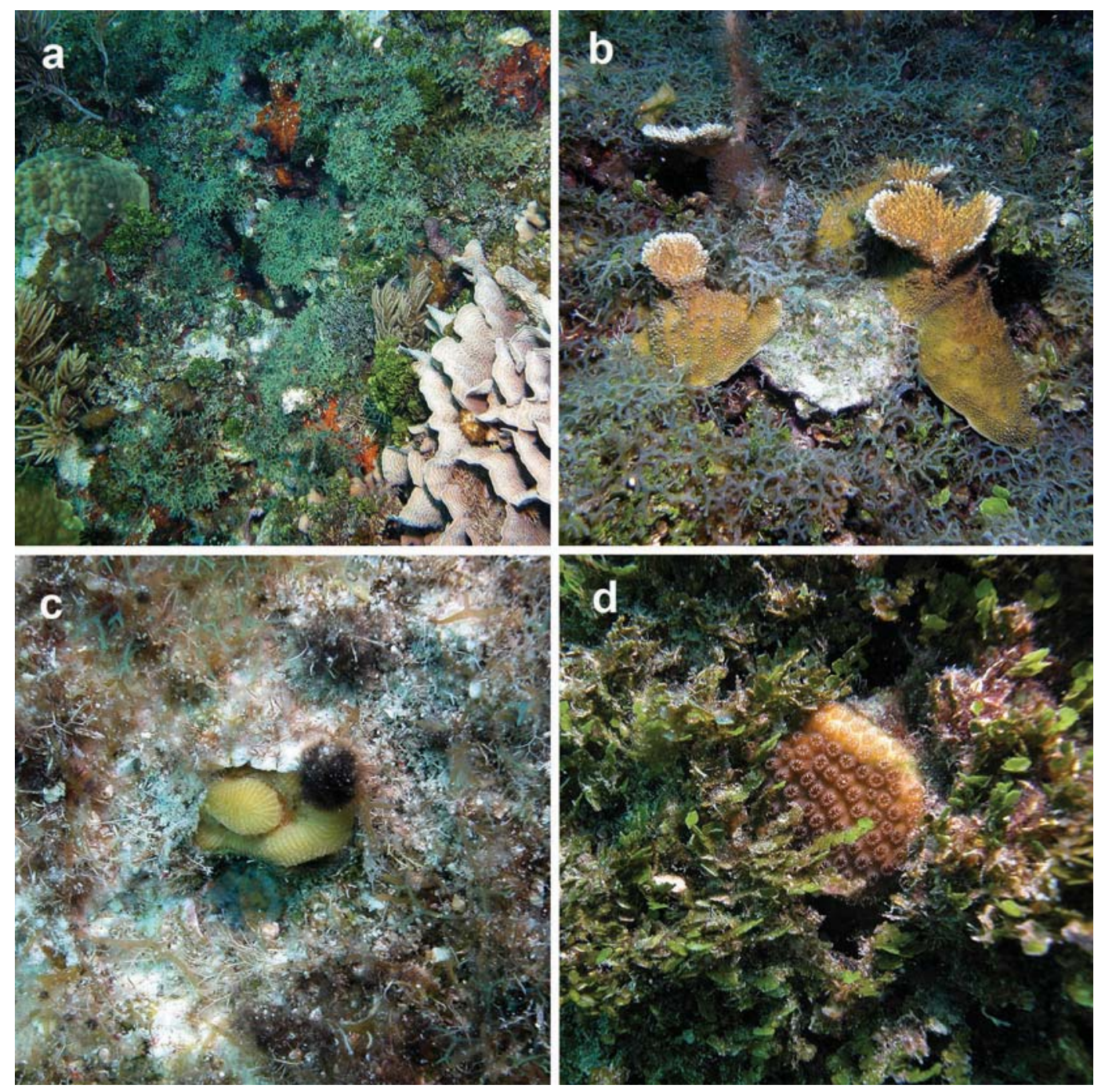

FIGURE 5. Macroalgae can be a dominant space occupier on degraded reefs and can inhibit coral recruitment at multiple life history stages. a, The macroalgae Dictyota spp. and Halimeda opuntia covered most of the benthos on this Belize reef, potentially inhibiting coral settlement. b, Recruits of Acropora palmata surrounded by Dictyota sp. c, A new recruit of Diploria sp. surrounded by Gelidiella, Jania, Dictyota, and the cyanobacterium Dichothrix sp. d, Montastraea annularis overgrown by Halimeda sp. (All photographs by Raphael Ritson-Williams.)

Reduced coral recruitment in algal-dominated reefs (Edmunds and Carpenter, 2001; Birrell et al., 2005) is thought to be in part the consequence of chemically induced mortality or the increased biomass of fleshy algae actually functioning as a reservoir for coral pathogens (Littler and Littler, 1997; Nugues et al., 2004). Bak and Borsboom (1984) proposed that the reduction in water flow adjacent to macroalgae could cause increased coral mortality through changes in the flow regime and increased allelochemical concentrations. Most recently, enhanced microbial activity caused by algal exudates has been proposed as a mechanism of competition (Smith et al., 2006; Vermeij et al., 2009). Kline et al. (2006) determined that elevated levels of dissolved organic carbon, which can occur in areas of high algal biomass, increased the growth rate of microbes living in the mucopolysaccharide layer of corals. These studies all suggest that the detrimental effect of algae on corals could be mediated by several properties of macrophytes.

On modern reefs, algal-related post-settlement mortality probably decreases the population density of coral 
recruits. Vermeij (2006) compared his recruitment study in Curacao from 1998 to 2004 to that of Van Moorsel (1989) from 1979 to 1981 , using the same method in the same location. Recruit densities on the topsides of settlement panels in the more recent study were 5.16 times lower and recruitment on the undersides was 1.14 times lower than the 1979-1981 study. Macroalgae had replaced CCA as the dominant topside space occupier, creating a less-suitable habitat for coral recruitment compared to the crustose algae that had dominated the same site roughly 20 years earlier. In places where Diadema urchin recovery and grazing have reduced algal abundance, the population density of juvenile corals has increased (Edmunds and Carpenter, 2001; Aronson et al., 2004; Macintyre et al., 2005).

While herbivory can improve the recruitment potential by keeping reefs relatively free of algae, it can also be a potential cause of mortality for newly settled corals. Grazing rates on exposed outer surfaces of shallow reefs are extremely high, exceeding thousands of bites per square meter per day (Carpenter, 1986; Steneck and Dethier, 1994; Steneck and Lang, 2003). Bites, especially from parrotfish that graze deeply into carbonate substrates, would easily kill a newly settled coral. Few studies have documented recruit mortality resulting from fish grazing (Mumby et al., 2006), although it has been suggested as the cause of the low number of recruits observed on the top surface of settlement plates (Adjeroud et al., 2007). The herbivorous sea urchin Diadema antillarum was shown to be a significant agent of mortality for newly settled corals (Sammarco and Carleton, 1981). The highest mortality of newly settled corals is likely to occur on outer exposed surfaces where algal growth rates and herbivore grazing rates are greatest and rates of sedimentation are highest. In shallow reef habitats where algal growth and herbivory rates are greatest, coral recruitment is greater in subcryptic microhabitats (Bak and Engel, 1979). However, which microhabitats increase post-settlement survival has rarely been tested (but see Babcock and Mundy, 1996).

\section{Post-Settlement Growth Rates}

Given the vulnerability of small size classes, the adaptive advantages of rapid growth rates are obvious. Coral recruit survival is not merely a function of the attributes of the settlement substrate but also of the coral's ability to resist overgrowth by neighboring encrusting invertebrates and algae (Richmond, 1997). As new corals grow, their mortality rates decline (Vermeij and Sandin, 2008), and they are less likely to be overgrown by competitors
(Hughes and Jackson, 1985). Often, however, the slow growth rates of newly settled corals make this a losing battle, and early post-settlement mortality is generally high (Figure 6; Bak and Engel, 1979; Edmunds, 2000; Vermeij and Sandin, 2008). Even in a controlled environment, laboratory studies showed that a coral that remains less than $3 \mathrm{~mm}$ in diameter for two or three months has only a $20 \%$ chance of survival (Rylaarsdam, 1983). Field studies report a huge amount of variance in early post-settlement mortality. Babcock (1985) found post-settlement survivorship over the first three to six months ranged from $16 \%$ to $71 \%$, whereas more recently Box and Mumby (2007) determined a monthly estimated mortality rate for Agaricia agaricites to be $3.5 \%$ per month. Annual juvenile coral survivorship estimates range from $0 \%$ to $77 \%$ (Smith, 1992; Wittenberg and Hunte, 1992; Maida et al., 1994; Smith, 1997; Edmunds, 2000).

Different species of corals have distinctly different rates of growth and ability to recover following a disturbance (Wakeford et al., 2008). Specifically, some of the Indo-Pacific acroporid corals (e.g., Acropora tenuis) are extremely "weedy" and are capable of growing nearly $6 \mathrm{~cm}$ in 1.5 years (Omori et al., 2008); this translates to an average growth rate of $3.2 \mathrm{~mm} /$ month compared to the much slower growth rates reported for Oxypora sp. as ranging between 0.2 and $0.5 \mathrm{~mm} /$ month (Babcock and Mundy, 1996).

Settlement habitat also influences growth rates of newly settled corals. Subcryptic habitats protect coral recruits from stresses and disturbances common on outer reef surfaces, but they will invariably have lower productivity potential. Diameters of Platygyra sp. and Oxypora sp. settlers increased one-quarter to one-half as fast in cryptic undersides than they did on upper exposed surfaces for the two species, respectively (Babcock and Mundy, 1996). Importantly, however, new recruits that selected subcryptic microhabitats had higher survivorship despite their slower growth rates (Babcock and Mundy, 1996).

\section{VARIABILITY OF POST-SETTLEMENT SURVIVAL AND GROWTH: THE ROLES OF BIODIVERSITY AND LIFE HISTORY STRATEGIES}

Before the disease-induced Acropora spp. decline in the Caribbean, fundamental differences existed between acroporid-dominated reefs of the Caribbean and Indo-Pacific regions. Caribbean reefs are largely built by two species of Acropora. Both species recruit rarely (Rylaarsdam, 1983; 

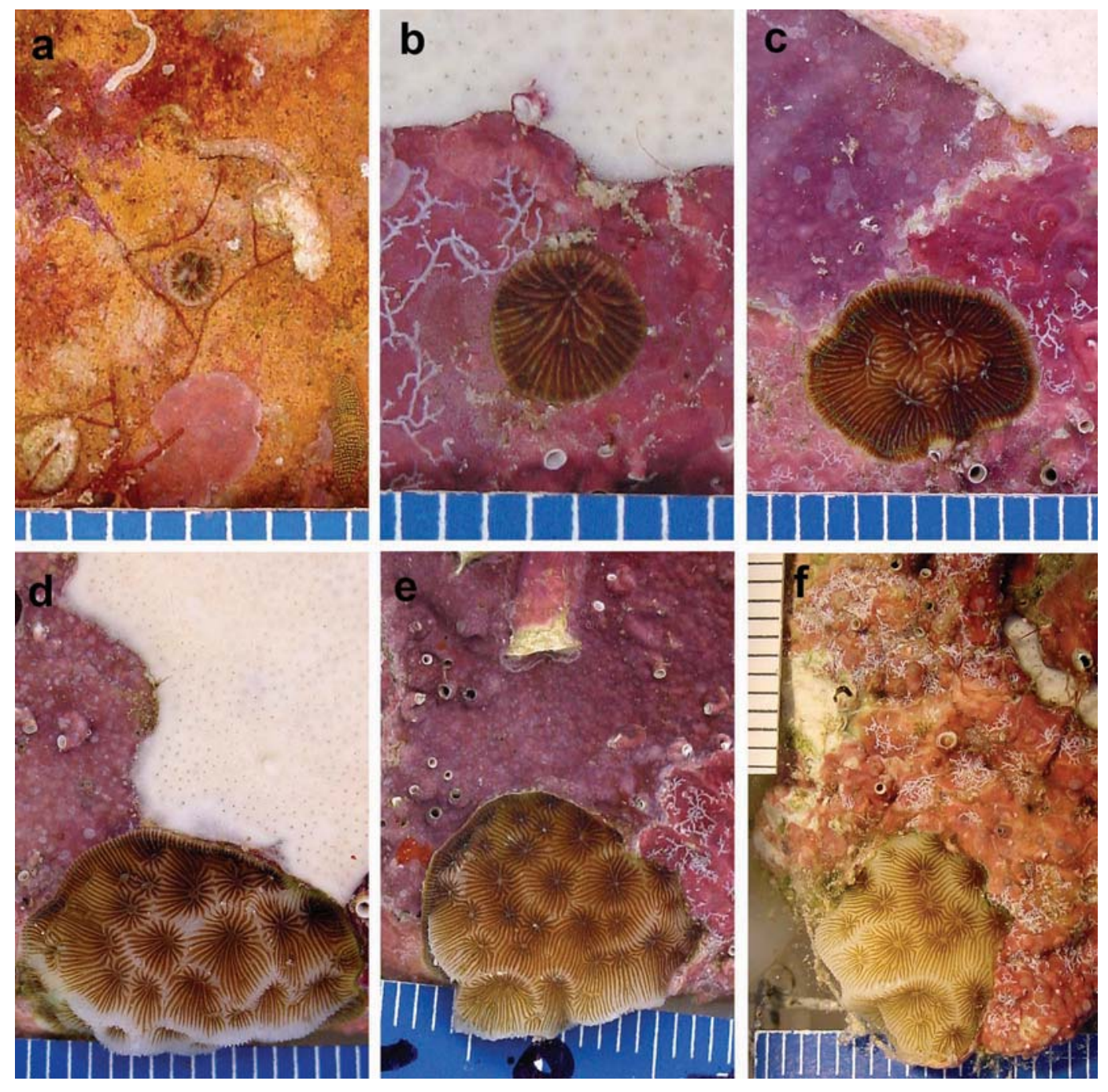

FIGURE 6. A time series of the growth of Agaricia sp. settled on a terracotta tile in Bonaire over 3.75 years. After March 2007 (e), this recruit is being overgrown by the coralline alga Titanoderma prototypum, a known settlement-facilitating species, illustrating just how hazardous the settlement environment can be. a, June 2004, recruit diameter is $1.3 \mathrm{~mm}$; b, March 2005, $3.4 \mathrm{~mm}$; c, July 2005, $8.4 \mathrm{~mm}$; d, June 2006, $15.2 \mathrm{~mm}$; e, March 2007, $16.0 \mathrm{~mm}$; f, March 2008, $12.0 \mathrm{~mm}$. One segment on the scale bar = $1 \mathrm{~mm}$. (All photographs by Suzanne Arnold.)

Sammarco, 1985), but their clonal growth created massive monocultures of rapidly growing reefs capable of keeping up with rising sea level (Adey, 1978). In contrast, there are two orders of magnitude more species of Acropora on Indo-Pacific coral reefs, and the population density of their recruits are also orders of magnitude greater on Indo-Pacific reefs than on Caribbean reefs (Hughes et al., 1999).

Although the high diversity of acroporid corals in the Pacific spans the spectrum of life history characteristics from weeds (i.e., high reproductive output and rapid growth rate; Omori et al., 2008) to trees (i.e., competitively dominant, large colonies; Baird and Hughes, 2000), the two acroporid species comprising Caribbean reefs require long adult lives and considerable clonal propagation. However, since the acroporid die-off in the early 1980s, Caribbean reefs have fundamentally changed. Because of the resultant algal phase shift (Hughes, 1994), acroporid reefs have become hostile to the rare acroporid recruits, and they have lost their receptivity for reattachment of encrusting fragments (Williams et al., 2008). These changes on many 
Caribbean reefs may be the primary reason why they appear less capable of recovering from widespread disturbances such as coral disease and bleaching.

The massive, slow-growing coral Montastraea annularis is also a broadcast spawner and framework builder in the Caribbean. It also has very low rates of recruitment (Hughes and Tanner, 2000) and thus requires long adult life to establish its dominance. Although it dominates Caribbean reefs today (Kramer, 2003) and is relatively hardy, it too has shown elevated levels of disease in recent years (Pantos et al., 2003) and has increased susceptibility to disease after bleaching (Miller et al., 2006). Again, the longterm prognosis for this Caribbean reef builder is poor.

Weedy, brooding species such as Agaricia spp. and Porites spp. are the thrust behind the current rates of coral recruitment in the Caribbean. The Caribbean brooder Agaricia agaricites is often the most abundant recruit on Caribbean reefs in recent times (Bak and Engel, 1979). This species has well-documented high rates of recruitment and adequate sediment-rejection capabilities yet regenerates poorly from lesions and is often outcompeted by other corals (Bak and Engel, 1979). In the past 30 years Agaricia tenuifolia has replaced other corals to dominate the community on two reefs that had historically different community compositions (Aronson et al., 2004).The increasing community dominance observed for Porites astreoides at six sites in the Caribbean is being driven by a constant recruitment rate coinciding with reduced percent cover of other coral species (Green et al., 2008).

It is possible that these life history-related differences are fundamentally changing Caribbean reefs. Are Caribbean reefs today following the paths of forests and other marine ecosystems in their shift to weedy, stress-tolerant species? (see Knowlton, 2001). A recovery such as seen in Palau following the 1998 bleaching event, where sexual recruitment and remnant regrowth were equal contributors (Golbuu et al., 2007), has yet to be recorded in the Caribbean. Success stories of Caribbean recoveries led by broadcast spawning species are scarce (but see Idjadi et al., 2006). Thus, the relative importance of sexual versus asexual reproduction to recovery in the Caribbean needs to be addressed by long-term observations with particular focus on recovery following large-scale disturbances such as major storms and bleaching events.

Thus, it seems that Caribbean reefs were built by corals that have been successful since the Pleistocene (Pandolfi and Jackson, 2006) with a strategy of low recruitment, considerable clonal growth, and low postsettlement mortality. However, that strategy may not be broadly viable today, given the global climate trajectory
(Hoegh-Guldberg et al., 2007) and patterns of human activities. While Indo-Pacific reefs are not immune to declines in rates of coral recruitment in recent years (Wakeford et al., 2008), the higher biodiversity and range of recruitment and post-recruitment strategies (e.g., high rates of growth) allow reefs there to be more resilient.

\section{CONCLUSIONS}

Coral mortality has increased in recent decades, making coral recruitment more important than ever before in sustaining coral reef ecosystems and contributing to their resilience. We identified three critical sequential phases to the recruitment process of corals: larval availability, larval settlement, and post-settlement ecology. All three factors are necessary for coral recruitment and, ultimately, for maintenance or recovery of coral reef ecosystems.

Most coral planulae available for recruitment are probably from relatively local reproduction and relatively short-distance connectivity. As adult coral abundance declines, both fertilization success and the effective dispersal distance of corals (see Figure 3B) will likely decline as well. Physiological stress on reproducing corals might also result in fewer and possibly weaker coral larvae arriving, thereby reducing the per capita rate of settlement success.

Once in the vicinity of a coral reef, settling corals respond to a hierarchy of environmental cues both in the water and from the reef. Several studies have identified organisms that facilitate or inhibit the settlement and metamorphosis of corals. Crustose coralline algae can facilitate coral settlement but, disturbingly, this group of algae is becoming rarer on coral reefs as macroalgae become increasingly dominant. Macroalgae are known inhibitors of settlement, which may result from their ability to rapidly occupy settlement habitat, their suite of secondary metabolites, their microbial communities, or a combination of some or all of these mechanisms.

Stressors that impact multiple life history stages of corals have the most potential to greatly reduce coral recruitment. Poor water quality (such as sedimentation and increased temperatures) and the increased abundance of macroalgae are known to decrease coral recruitment and negatively impact corals at many different life history stages. Human impacts on the water quality of marine systems continue to grow, and few locations remain untouched (Halpern et al., 2008). These and other stressors may decrease the reproductive output of corals, physiologically stress the larvae, block subcryptic nursery habitats, create negative settlement cues, and result in increased post-settlement mortality. 
Globally, many Indo-Pacific reefs have higher rates of settlement, recruitment, and recovery from disturbances, which could be the result of higher biodiversity in the region. In contrast, Caribbean reefs may have evolved a strategy of low recruitment and considerable clonal growth, with low post-settlement mortality for its few reef-building acroporid corals. Unfortunately, that strategy may be ineffective in the future given the global climate trajectory of higher ocean temperatures, acidification, and greater disturbance from tropical storms, which will continue to physiologically stress corals. Because Indo-Pacific reefs have two orders of magnitude more acroporid species, weedy and potentially resilient strategies could succeed. If current trends continue on modern reefs, it is possible that reefs in the future will differ from those of the recent past.

\section{ACKNOWLEDGMENTS}

Funding for our research on these various topics was provided, in part, by the Smithsonian Marine Science Network. Special thanks to Klaus Ruetzler and Michael Carpenter for facilitating research for RRW, VP, NF, SA, and RS at the Carrie Bow Field Station in Belize. SA and RS thank the Coral Reef Targeted Research Project (Connectivity), National Fish and Wildlife Fund, Wildlife Conservation Society and the Bonaire Marine National Park (STINAPA). VP and RRW thank the Mote "Protect Our Reefs" grant program. This is contribution number 849 of the Caribbean Coral Reef Ecosystems Program (CCRE), Smithsonian Institution, supported in part by the Hunterdon Oceanographic Research Fund, and Smithsonian Marine Station at Fort Pierce (SMSFP) contribution number 765 .

\section{LITERATURE CITED}

Adey, W. 1978. Coral Reef Morphogenesis: A Multidimensional Model. Science, 202:831-837.

Adjeroud, M., L. Penin, and A. Carroll. 2007. Spatio-temporal Heterogeneity in Coral Recruitment around Moorea, French Polynesia: Implications for Population Maintenance. Journal of Experimental Marine Biology and Ecology, 341:204-218.

Aerts, L.A.M., and R. W. M. van Soest. 1997. Quantification of Sponge/ Coral Interactions in a Physically Stressed Reef Community, NE Colombia. Marine Ecology Progress Series, 148:125-134.

Albright, R., B. Mason, and C. Langdon. 2008. Effect of Aragonite Saturation State on Settlement and Post-settlement Growth of Porites astreoides Larvae. Coral Reefs, 27:485-490.

Aronson, R.B., I. G. Macintyre, C. M. Wapnick, and W. O. O’Neill. 2004. Phase Shifts, Alternative States, and the Unprecedented Convergence of Two Reef Systems. Ecology, 85:1876-1891.
Ayre, D. J., and T. P. Hughes. 2000. Genotypic Diversity and Gene Flow in Brooding and Spawning Corals along the Great Barrier Reef, Australia. Evolution, 54:1590-1605.

- 2004. Climate Change, Genotypic Diversity and Gene Flow in Reef-Building Corals. Ecology Letters, 7:273-278.

Babcock, R. 1985. Growth and Mortality in Juvenile Corals: The First Year. Proceedings of the 8th International Coral Reef Symposium, 2:1197-1202.

- 1995. Synchronous Multispecific Spawning on Coral Reefs: Potential for Hybridization and Roles of Gamete Recognition. Reproduction, Fertility and Development, 7:943-950.

Babcock, R., and C. Mundy. 1996. Coral Recruitment: Consequences of Settlement Choice for Early Growth and Survivorship in Two Scleractinians. Journal of Experimental Marine Biology and Ecology, 206:179-201.

Babcock, R. C. and A. J. Heyward. 1986. Larval Development of Certain Gamete-Spawning Scleractinian Corals. Coral Reefs, 5:111-116.

Baird, A. H., R.C. Babcock, and C. P. Mundy. 2003. Habitat Selection by Larvae Influences the Depth Distribution of Six Common Coral Species. Marine Ecology Progress Series, 252:289-293.

Baird, A. H., J. Gilmour, T. M. Kamiki, M. Nonada, M. S. Pratchett, H. H. Yamamoto, and H. Yamasaki. 2006. Temperature Tolerance of Symbiotic and Non-symbiotic Coral Larvae. Proceedings of the 10th International Coral Reef Symposium, 1:351-358.

Baird, A. H., and T. P. Hughes. 2000. Competitive Dominance by Tabular Corals: An Experimental Analysis of Recruitment and Survival of Understory Assemblages. Journal of Experimental Marine Biology and Ecology, 251:117-132.

Baird, A. H., and A. N. C. Morse. 2004. Induction of Metamorphosis in Larvae of the Brooding Corals Acropora palifera and Stylophora pistillata. Marine and Freshwater Research, 55:469-472.

Bak, R. P. M., and J. L. A. Borsboom. 1984. Allelopathic Interaction between a Reef Coelenterate and Benthic Algae. Oecologia (Berlin), 63:194-198.

Bak, R. P. M., and M. S. Engel. 1979. Distribution, Abundance and Survival of Juvenile Hermatypic Corals (Scleractinia) and the Importance of Life History Strategies in the Parent Coral Community. Marine Biology, 54:341-352.

Bassim, K. M., and P. W. Sammarco. 2003. Effects of Temperature and Ammonium on Larval Development and Survivorship in a Scleractinian Coral (Diploria strigosa). Marine Biology, 142:241-252.

Baums, I. B., M. W. Miller, and M. E. Hellberg. 2005. Regionally Isolated Populations of an Imperiled Caribbean Coral, Acropora palmata. Molecular Ecology, 14:1377-1390.

. 2006. Geographic Variation in Clonal Structure in a ReefBuilding Caribbean Coral, Acropora palmata. Ecological Monographs, 76:503-519.

Bennett, C. E., and D. J. Marshall. 2005. The Relative Energetic Costs of the Larval Period, Larval Swimming and Metamorphosis for the Ascidian Diplosoma listerianum. Marine and Freshwater Behaviour and Physiology, 38:21-29.

Birkeland, C. 1977. The Importance of Rate of Biomass Accumulation in Early Successional Stages of Benthic Communities to the Survival of Coral Recruits. In Proceedings of the 3rd International Coral Reef Symposium, Miami, 1:15-21.

Birrell, C. L., L. J. McCook, and B. L. Willis. 2005. Effects of Algal Turfs and Sediment on Coral Settlement. Marine Pollution Bulletin, 51:408-414.

Birrell, C. L., L. J. McCook, B. L. Willis, and L. Harrington. 2008a. Chemical Effects of Macroalgae on Larval Settlement of the Broadcast Spawning Coral Acropora millepora. Marine Ecology Progress Series, 362:129-137. 
Birrell, C. L., L. J. McCook, B. L. Willis, and G. A. Diaz-Pulido. 2008b. Effects of Benthic Algae on the Replenishment of Corals and the Implications for the Resilience of Coral Reefs. Oceanography and Marine Biology: An Annual Review, 46:25-63.

Box, S. J., and P. J. Mumby. 2007. Effect of Macroalgal Competition on Growth and Survival of Juvenile Caribbean corals. Marine Ecology Progress Series, 342:139-149.

Bruno, J. F., and E. R. Selig. 2007. Regional Decline of Coral Cover in the Indo-Pacific: Timing, Extent, and Subregional Comparisons. PLOS One, 8:1-8.

Carlon, D. B. 2001. Depth-Related Patterns of Coral Recruitment and Cryptic Suspension-Feeding Invertebrates on Guana Island, British Virgin Islands. Bulletin of Marine Science, 68:525-541.

- 2002. Production and Supply of Larvae as Determinants of Zonation in a Brooding Tropical Coral. Journal of Experimental Marine Biology and Ecology, 268:33-46.

Carlon, D. B., and R. R. Olson. 1993. Larval Dispersal Distance as an Explanation for Adult Spatial Pattern in Two Caribbean Reef Corals. Journal of Experimental Marine Biology and Ecology, 173:247-263.

Carpenter, R. C. 1986. Partitioning Herbivory and Its Effects on Coral Reef Algal Communities. Ecological Monographs, 56:343-363.

Chiu, J. M. Y., T. Y. T. Ng, W. X. Wang, V. Thiyagarajan, and P. Y. Qian. 2007. Latent Effects of Larval Food Limitation on Filtration Rate, Carbon Assimilation and Growth in Juvenile Gastropod Crepidula onyx. Marine Ecology Progress Series, 343:173-182.

Chiu, J. M. Y., H. Wang, V. Thiyagarajan, and P. Y. Qian. 2008. Differential Timing of Larval Starvation Effects on Filtration Rate and Growth in Juvenile Crepidula onyx. Marine Biology, 154:91-98.

Chornesky, E. A., and E. C. Peters. 1987. Sexual Reproduction and Colony Growth in the Scleractinian Coral Porites astreoides. Biological Bulletin, 172:161-177.

Coll, J. C., B. F. Bowden, G. V. Meehan, G. M. Konig, A. R. Carroll, D. M. Tapiolas, P. M. Aliño, A. Heaton, R. De Nys, P. A. Leone, M. Maida, T. L. Aceret, R. H. Willis, R. C. Babcock, B. L. Willis, Z. Florian, M. N. Clayton, and R. L. Miller. 1994. Chemical Aspects of Mass Spawning in Corals. I. Sperm-Attractant Molecules in the Eggs of the Scleractinian Coral Montipora digitata. Marine Biology, 118:117-182.

Coma, R., and H. R. Lasker. 1997. Effects of Spatial Distribution and Reproductive Biology on In Situ Fertilization Rates of a BroadcastSpawning Invertebrate. Biological Bulletin, 193:20-29.

Connell, J. H. 1997. Disturbance and Recovery of Coral Assemblages. Coral Reefs, 16:S101-S113.

Connell, J. H., T. P. Hughes, and C. C. Wallace. 1997. A 30-Year Study of Coral Abundance, Recruitment, and Disturbance at Several Scales in Space and Time. Ecological Monographs, 67:461-488.

Cowen, R. K., K. M. M. Lwiza, S. Sponaugle, C. B. Paris, and D. B. Olson. 2000. Connectivity of Marine Populations: Open or Closed? Science, 287:857-859.

Cowen, R. K., C. B. Paris, and A. Srinivasan. 2006. Scaling of Connectivity in Marine Populations. Science, 311:522-527.

de Ruyter van Steveninck, E. D., L. L. Van Mulekom, and A. M. Breeman. 1988. Growth Inhibition of Lobophora variegata (Lamouroux) Womersley by Scleractinian Corals. Journal of Experimental Marine Biology and Ecology, 115:169-178.

Doherty, P., and T. Fowler. 1994. An Empirical Test of Recruitment Limitation in a Coral Reef Fish. Science, 263:935-939.

Done, T. 1992. Phase Shifts in Coral Reef Communities and Their Ecological Significance. Hydrobiologia, 247:121-132.

Downs, C. A., C. M. Woodley, R. H. Richmond, L. L. Lanning, and R. Owen. 2005. Shifting the Paradigm of Coral-Reef 'Health' Assessment. Marine Pollution Bulletin, 51:486-494.
Edmunds, P. J. 2000. Patterns in the Distribution of Juvenile Corals and Coral Reef Community Structure in St. John, US Virgin Islands. Marine Ecology Progress Series, 202:113-124.

Edmunds, P. J., J. F. Bruno, and D. B. Carlon. 2004. Effects of Depth and Microhabitat on Growth and Survivorship of Juvenile Corals in the Florida Keys. Marine Ecology Progress Series, 278:115-124.

Edmunds, P. J., and R. C. Carpenter. 2001. Recovery of Diadema antillarum Reduces Macroalgal Cover and Increases Abundance of Juvenile Corals on a Caribbean Reef. Proceedings of the National Academy of Sciences of the United States of America, 98: 5067-5071.

Edmunds, P. J., R. D. Gates, and D. F. Gleason. 2001. The Biology of Larvae from the Reef Coral Porites astreoides, and Their Response to Temperature Disturbances. Marine Biology, 139:981-989.

Edmunds, P. J., R. D. Gates, W. Leggat, O. Hoegh-Guldberg, and L. AllenRequa. 2005. The Effect of Temperature on the Size and Population Density of Dinoflagellates in Larvae of the Reef Coral Porites astreoides. Invertebrate Biology, 124:185-193.

Fabricius, K. E., and J. Metzner. 2004. Scleractinian Walls of Mouths: Predation on Coral Larvae by Corals. Coral Reefs, 23:245-248.

Fadlallah, Y. H. 1983. Sexual Reproduction, Development and Larval Biology in Scleractinian Corals. Coral Reefs, 2:129-150.

Fautin, D. G. 2003. Reproduction of Cnidaria. Canadian Journal of Zoology, 80:1735-1754.

Fearon, R. J., and A. M. Cameron. 1996. Larvotoxic Extracts of the Hard Coral Goniopora tenuidens: Allelochemicals That Limit Settlement of Potential Competitors? Toxicon, 34:361-367.

Fenner, D., and K. Banks. 2004. Orange Cup Coral Tubastraea coccinea Invades Florida and the Flower Garden Banks, Northwestern Gulf of Mexico. Coral Reefs, 23:505-507.

Fine, M., H. Zibrowius, and Y. Loya. 2001. Oculina patagonica: A NonLessepsian Scleractinian Coral Invading the Mediterranean Sea. Marine Biology, 138:1195-1203.

Foster, N. L., S. J. Box, and P. J. Mumby. 2008. Competitive Effects of Macroalgae on the Fecundity of the Reef-Building Coral Montastraea annularis. Marine Ecology Progress Series, 367:143-152.

Gaines, S., and J. Roughgarden. 1985. Larval Settlement Rate: A Leading Determinant of Structure in an Ecological Community of the Marine Intertidal Zone. Proceedings of the National Academy of Sciences of the United States of America, 82:3707-3711.

Gardner, T. A., I. M. Cote, J. A. Gill, A. Grant, and A. R. Watkinson. 2003. Long-term Region-wide Declines in Caribbean Corals. Science, 301:958-960.

Gilmour, J. 1999. Experimental Investigation into the Effects of Suspended Sediment on Fertilization, Larval Survival and Settlement in a Scleractinian Coral. Marine Biology, 135:451-462.

Gleason, D. F., P. J. Edmunds, and R. D. Gates. 2006. Ultraviolet Radiation Effects on the Behavior and Recruitment of Larvae from the Reef Coral Porites astreoides. Marine Biology, 148:503-512.

Golbuu, Y., and R. H. Richmond. 2007. Substratum Preferences in Planula Larvae of Two Species of Scleractinian Corals, Goniastrea retiformis and Stylaraea punctata. Marine Biology, 152:639-644.

Golbuu, Y., S. Victor, L. Penland, D. Idip, C. Emaurois, K. Okaji, H. Yukihira, A. Iwase, and R. van Woesik. 2007. Palau's Coral Reefs Show Differential Habitat Recovery Following the 1998 Bleaching Event. Coral Reefs, 26:319-332.

Graham, E. M., A. H. Baird, and S. R. Connolly. 2008. Survival Dynamics of Scleractinian Coral Larvae and Implications for Dispersal. Coral Reefs, 27:529-539.

Green, D. H., P. J. Edmunds, and R. C. Carpenter. 2008. Increasing Relative Abundance of Porites astreoides on Caribbean Reefs Mediated by an Overall Decline in Coral Cover. Marine Ecology Progress Series, 359:1-10. 
Guzman, H. M., K. A. Burns, and J. B. C. Jackson. 1994. Injury, Regeneration and Growth of Caribbean Reef Corals after a Major Oil Spill in Panama. Marine Ecology Progress Series, 105:231-241.

Hadfield, M. G., and V. J. Paul. 2001. Natural Chemical Cues for Settlement and Metamorphosis of Marine Invertebrate Larvae. In Marine Chemical Ecology, ed. J. McClintock and B. Baker, pp. 431-462. Boca Raton: CRC Press.

Halpern, B. S., S. Walbridge, K. A. Selkoe, C. V. Kappel, F. Micheli, C. D’Agrosa, J. F. Bruno, K. S. Casey, C. Ebert, H. E. Fox, R. Fujita, D. Heinemann, H. S. Lenihan, E. M. P. Madin, M. T. Perry, E. R. Selig, M. Spalding, R. Steneck, and R. Watson. 2008. A Global Map of Human Impact on Marine Ecosystems. Science, 319:948-952.

Harrington, L., K. Fabricius, G. De'ath, and A. Negri. 2004. Recognition and Selection of Settlement Substrata Determine Post-settlement Survival in Corals. Ecology, 85:3428-3437.

Harriott, V. J. 1983. Reproductive Seasonality, Settlement, and Postsettlement Mortality of Pocillopora damicornis (Linnaeus), at Lizard Island, Great Barrier Reef. Coral Reefs, 2:151-157.

Harrison, P. L., R. C. Babcock, G. D. Bull, J. K. Oliver, C. C. Wallace, and B. L. Willis. 1984. Mass Spawning in Tropical Reef Corals. Science, 223:1186-1189.

Hatta, M., H. Fukami, W. Q. Wang, M. Omori, K. Shimoike, T. Hayashibara, Y. Ina, and T. Sugiyama. 1999. Reproductive and Genetic Evidence for a Reticulate Evolutionary History of Mass-Spawning Corals. Molecular Biology and Evolution, 16:1607-1613.

Heintz, R. A., S. D. Rice, A. C. Wertheimer, R. F. Bradshaw, F. P. Thrower, J. E. Joyce, and J. W. Short. 2000. Delayed Effects on Growth and Marine Survival of Pink Salmon Oncorbynchus gorbuscha after Exposure to Crude Oil During Embryonic Development. Marine Ecology Progress Series, 208:205-216.

Hellberg, M. E. 2007. Footprints on Water: The Genetic Wake of Dispersal among Reefs. Coral Reefs, 26:463-473.

Heyward, A. J., and A. P. Negri. 1999. Natural Inducers for Coral Larval Metamorphosis. Coral Reefs, 18:273-279.

Hodgson, G. 1990. Sediment and the Settlement of Larvae of the Reef Coral Pocillopora damicornis. Coral Reefs, 9:41-43.

Hoegh-Guldberg, O., P. J. Mumby, A. J. Hooten, R. S. Steneck, P. Greenfield, E. Gomez, C. D. Harvell, P. F. Sale, A. J. Edwards, K. Caldeira, N. Knowlton, C. M. Eakin, R. Iglesias-Prieto, N. Muthiga, R. H. Bradbury, A. Dubi, and M. E. Hatziolos. 2007. Coral Reefs under Rapid Climate Change and Ocean Acidification. Science, 318:1737-1742.

Holling, C. S. 1973. Resilience and Stability of Ecological Systems. Annual Review of Ecology and Systematics, 4:1-23.

Hughes, T. 1984. Population Dynamics Based on Individual Size Rather Than Age: A General Model with a Reef Coral Example. American Naturalist, 123:778-795.

Hughes, T., and J. B. C. Jackson. 1985. Population Dynamics and Life Histories of Foliaceous Corals. Ecological Monographs, 55:141166.

Hughes, T. P. 1994. Catastrophes, Phase-Shifts, and Large-Scale Degradation of a Caribbean Coral Reef. Science, 265:1547-1551.

Hughes, T. P., A. H. Baird, E. A. Dinsdale, N. A. Moltschaniwkyj, M. S. Pratchett, J. E. Tanner, and B. L. Willis. 1999. Patterns of Recruitment and Abundance of Corals along the Great Barrier Reef. Nature (London), 397:59-63.

Hughes, T. P., D. R. Bellwood, C. Folke, R. Steneck, and J. Wilson. 2005. New Paradigms for Supporting the Resilience of Marine Ecosystems. Trends in Ecology and Evolution, 20:380-386.

Hughes, T. P., M. J. Rodrigues, D. R. Bellwood, D. Ceccarelli, O. Hoegh-Guldberg, L. McCook, N. Moltschaniwskyj, M. S. Pratchett, R. S. Steneck, and B. Willis. 2007. Phase Shifts, Herbivory, and the Resilience of Coral Reefs to Climate Change. Current Biology, 17:360-365.
Hughes, T. P., and J. E. Tanner. 2000. Recruitment Failure, Life Histories, and Long-Term Decline of Caribbean Corals. Ecology, $81: 2250-2263$

Humphrey, C., M. Weber, C. Lott, T. Cooper, and K. Fabricius. 2008. Effects of Suspended Sediments, Dissolved Inorganic Nutrients and Salinity on Fertilisation and Embryo Development in the Coral Acropora millepora (Ehrenberg, 1834). Coral Reefs, 27:837-850.

Idjadi, J. A., S. C. Lee, J. F. Bruno, W. F. Precht, L. Allen-Requa, and P. J. Edmunds. 2006. Rapid Phase-Shift Reversal on a Jamaican Coral Reef. Coral Reefs, 25:209-211.

Jackson, J. B. C., and L. Buss. 1975. Allelopathy and Spatial Competition among Coral Reef Invertebrates. Proceedings of the National Academy of Sciences of the United States of America, 72:5160-5163.

Johnson, C. R., C. D. Muir, and A.-L. Reysenback. 1991. Characteristic Bacteria Associated with the Surfaces of Coralline Algae: A Hypothesis for Bacterial Induction of Marine Invertebrate Larvae. Marine Ecology Progress Series, 74:281-294.

Jompa, J., and L. J. McCook. 2003. Contrasting Effects of Turf Algae on Corals: Massive Porites spp. Are Unaffected by Mixed-Species Turfs, But Killed by the Red Alga Anotrichium tenue. Marine Ecology Progress Series, 258:79-86.

Jones, C. G., J. H. Lawton, and M. Shachak. 1994. Organisms as Ecosystem Engineers. Oikos, 69:373-386.

- 1997. Positive and Negative Effects of Organisms as Physical Ecosystem Engineers. Ecology, 78:1946-1957.

Kline, D. I., N. M. Kuntz, M. Breitbart, N. Knowlton, and F. Rohwer. 2006. Role of Elevated Organic Carbon Levels and Microbial Activity in Coral Mortality. Marine Ecology Progress Series, 314:119-125.

Knowlton, N. 2001. The Future of Coral Reefs. Proceedings of the National Academy of Sciences of the United States of America, 98:5419-5425.

Koop, K., D. Booth, A. Broadbent, J. Brodie, D. Bucher, D. Capone, J. Coll, W. Dennison, M. Erdmann, P. Harrison, O. Hoegh-Guldberg, P. Hutchings, G. B. Jones, A. W. D. Larkum, J. O’Neil, A. Steven, E. Tentori, S. Ward, J. Williamson, and D. Yellowlees. 2001. ENCORE: The Effect of Nutrient Enrichment on Coral Reefs. Synthesis of Results and Conclusions. Marine Pollution Bulletin, 42:91-120.

Kramer, P. A. 2003. Synthesis of Coral Reef Health Indicators for the Western Atlantic: Results of the AGRRA Program (1997-2000). Atoll Research Bulletin, 496:1-58.

Kuffner, I. B. 2001. Effects of Ultraviolet Radiation on Larval Recruitment of the Reef Coral, Pocillopora damicornis. Marine Ecology Progress Series, 217:251-261.

Kuffner, I. B., and V. J. Paul. 2004. Effects of the Benthic Cyanobacterium Lyngbya majuscula on the Larval Settlement of the Reef Corals Acropora surculosa and Pocillopora damicornis. Coral Reefs, 23:455-458.

Kuffner, I. B., L. J. Walters, M. A. Becerro, V. J. Paul, R. Ritson-Williams, and K. Beach. 2006. Inhibition of Coral Recruitment by Macroalgae and Cyanobacteria. Marine Ecology Progress Series, 323:107-117.

Lee, S. C. 2006. Habitat Complexity and Consumer-Mediated Positive Feedbacks on a Caribbean Coral Reef. Oikos, 112:442-447.

Levin, L. A. 2006. Recent Progress in Understanding Larval Dispersal: New Directions and Digressions. Integrative and Comparative Biology, 46:282-297.

Levitan, D. R., H. Fukami, J. Jara, D. Kline, T. M. McGovern, K. E. McGhee, C. A. Swanson, and N. Knowlton. 2004. Mechanisms of Reproductive Isolation among Sympatric Broadcast-Spawning Corals of the Montastraea annularis Species Complex. Evolution, 58:308-323.

Levitan, D. R., and T. M. McGovern. 2005. The Allee Effect in the Sea. Washington, D.C.: Island Press. 
Levitan, D. R., M. A. Sewell, and F. S. Chia. 1992. How Distribution and Abundance Influence Fertilization Success in the Sea Urchin Strongylocentrotus franciscanus. Ecology, 73:248-254.

Lewis, J. B. 1974. The Settlement Behavior of Planulae Larvae of the Hermatypic Coral Favia fragum (Esper). Journal of Experimental Marine Biology and Ecology, 15:165-172.

Lirman, D. 2001. Competition Between Macroalgae and Corals: Effects of Herbivore Exclusion and Increased Algal Biomass on Coral Survivorship and Growth. Coral Reefs, 19:392-399.

Littler, M. M., and D. S. Littler. 1997. Disease-Induced Mass Mortality of Crustose Algae on Coral Reefs Provides Rationale for the Conservation of Herbivorous Fish Stocks. Proceedings of the 8th International Coral Reef Symposium, 1:719-724.

Macintyre, I. G., P. W. Glynn, and F. Hinds. 2005. Evidence of the Role of Diadema antillarum in the Promotion of Coral Settlement and Survivorship. Coral Reefs, 24:273.

Maida, M., J. C. Coll, and P. W. Sammarco. 1994. Shedding New Light on Scleractinian Coral Recruitment. Journal of Experimental Marine Biology and Ecology, 180:189-202.

Maida, M., P. W. Sammarco, and J. C. Coll. 1995. Effects of Soft Corals on Scleractinian Coral Recruitment. I: Directional Allelopathy and Inhibition of Settlement. Marine Ecology Progress Series, 121:191-202.

Marshall, D. J., J. A. Pechenik, and M. J. Keough. 2003. Larval Activity Levels and Delayed Metamorphosis Affect Post-larval Performance in the Colonial Ascidian Diplosoma listerianum. Marine Ecology Progress Series, 246:153-162.

Maypa, A. P., and L. J. Raymundo. 2004. Algae-Coral Interactions. Mediation of Coral Settlement, Early Survival, and Growth by Macroalgae. Silliman Journal, 45:76-95.

Mayr, E. 1963. Animal Species and Evolution. Cambridge, Maine: Belknap Press.

McCook, L. J., J. Jompa, and G. Diaz-Pulido. 2001. Competition Between Corals and Algae on Coral Reefs: A Review of Evidence and Mechanisms. Coral Reefs, 19:400-417.

Miller, J., R. Waara, E. Muller, and C. Rogers. 2006. Coral Bleaching and Disease Combine to Cause Extensive Mortality on Reefs in the US Virgin Islands. Coral Reefs, 25:418

Miller, K., and C. Mundy. 2003. Rapid Settlement in Broadcast Spawning Corals: Implications for Larval Dispersal. Coral Reefs, 22:99-106.

Miller, S. E. 1993. Larval Period and Its Influence on Postlarval Life History: Comparison of Lecithotrophy and Facultative Planktotrophy in the Aeolid Nudibranch Phestilla sibogae. Marine Biology, 117:635-645.

Morse, A. N. C., K. Iwao, M. Baba, K. Shimoike, T. Hayashibara, and M. Omori. 1996. An Ancient Chemosensory Mechanism Brings New Life to Coral Reefs. Biological Bulletin, 191:149-154.

Morse, D. E., and A. N. C. Morse. 1991. Enzymatic Characterization of the Morphogen Recognized by Agaricia humilis (Scleractinian Coral) Larvae. Biological Bulletin, 181:104-122.

Morse, D. E., A. N. C. Morse, P. T. Raimondi, and N. Hooker. 1994. Morphogen-Based Chemical Flypaper for Agaricia humilis Coral Larvae. Biological Bulletin, 186:172-181.

Mumby, P. J., C. P. Dahlgren, A. R. Harborne, C. V. Kappel, F. Micheli, D. R. Brumbaugh, K. E. Holmes, J. M. Mendes, K. Broad, J. N. Sanchirico, K. Buch, S. Box, R. W. Stoffle, and A. B. Gill. 2006. Fishing, Trophic Cascades, and the Process of Grazing on Coral Reefs. Science, 311:98-101.

Mumby, P. J., and R. Steneck. 2008. Coral Reef Management and Conservation in the Light of Rapidly Evolving Ecological Paradigms. Trends in Ecology and Evolution, 23:555-563.

Mundy, C. N., and R. C. Babcock. 1998. Role of Light Intensity and Spectral Quality in Coral Settlement: Implications for Depth-Dependent Settlement? Journal of Experimental Marine Biology and Ecology, 223:235-255.
Negri, A. P., N. S. Webster, R. T. Hill, and A. J. Heyward. 2001. Metamorphosis of Broadcast Spawning Corals in Response to Bacteria Isolated from Crustose Algae. Marine Ecology Progress Series, 223:121-131.

Nishikawa, A., M. Katoh, and K. Sakai. 2003. Larval Settlement Rates and Gene Flow of Broadcast-Spawning (Acropora tenuis) and Planula-Brooding (Stylophora pistillata) Corals. Marine Ecology Progress Series, 256:87-97.

Nozawa, Y., and P. L. Harrison. 2008. Temporal Patterns of Larval Settlement and Survivorship of Two Broadcast-Spawning Acroporid Corals. Marine Biology 155:347-351.

Nugues, M. M., G. W. Smith, R. J. Van Hooindonk, M. I. Seabra, and R. P. M. Bak. 2004. Algal Contact as a Trigger for Coral Disease. Ecology Letters, 7:919-923.

Nugues, M. M., and A. M. Szmant. 2006. Coral Settlement onto Halimeda opuntia: A Fatal Attraction to an Ephemeral Substrate? Coral Reefs, 25:585-591.

Nyström, M., C. Folke, and F. Moberg. 2000. Coral Reef Disturbance and Resilience in a Human-Dominated Environment. Trends in Ecology and Evolution, 15:413-417.

Oliver, J., and R. Babcock. 1992. Aspects of the Fertilization Ecology of Broadcast Spawning Corals: Sperm Dilution Effects and In Situ Measurements of Fertilization. Biological Bulletin, 183: 409-417.

Omori, M., H. Fukami, H. Kobinata, and M. Hatta. 2001. Significant Drop of Fertilization of Acropora Corals in 1999. An After Effect of Heavy Coral Bleaching? Limnology and Oceanography, 46:704-706

Omori, M., K. Iwao, and M. Tamura. 2008. Growth of Transplanted Acropora tenuis 2 Years after Egg Culture. Coral Reefs, 27:165.

Palma, A. T., R. S. Steneck, and C. J. Wilson. 1999. Settlement-Driven, Multiscale Demographic Patterns of Large Benthic Decapods in the Gulf of Maine. Journal of Experimental Marine Biology and Ecology, 241:107-136.

Palumbi, S. R. 1994. Genetic Divergence, Reproductive Isolation, and Marine Speciation. Annual Review of Ecology and Systematics, 25:547-572.

Pandolfi, J. M., and J. B. C. Jackson. 2006. Ecological Persistence Interrupted in Caribbean Coral Reefs. Ecology Letters, 9:818-826.

Pandolfi, J. M., J. B. C. Jackson, N. Baron, R. H. Bradbury, H. M. Guzman, T. P. Hughes, C. V. Kappel, F. Micheli, J. C. Ogden, H. P. Possingham, and E. Sala. 2005. Are U.S. Coral Reefs on the Slippery Slope to Slime? Science, 307:1725-1726.

Pantos, O., R. P. Cooney, M. D. A. Le Tissier, M. R. Barer, A. G. O'Donnell, and J. C. Bythell. 2003. The Bacterial Ecology of a Plague-like Disease Affecting the Caribbean Coral Montastraea annularis. Environmental Microbiology, 5:370-382.

Pawlik, J. R. 1992. Chemical Ecology of the Settlement of Benthic Marine Invertebrates. Oceanography and Marine Biology: An Annual Review, 30:273-335.

Pawlik, J. R., L. Steindler, T. P. Henkel, S. Beer, and M. Ilan. 2007. Chemical Warfare on Coral Reefs: Sponge Metabolites Differentially Affect Coral Symbiosis In Situ. Limnology and Oceanography, 52:907-911.

Pechenik. J. A. 1990. Delayed Metamorphosis by Larvae of Benthic Marine Invertebrates. Does It Occur? Is There a Price to Pay? Ophelia, 32:63-94.

- 2002. Relationships Between Larval Nutritional Experience, Larval Growth Rates, Juvenile Growth Rates, and Juvenile Feeding Rates in the Prosobranch Gastropod Crepidula fornicata. Journal of Experimental Marine Biology and Ecology, 280:63-78.

. 2006. Larval Experience and Latent Effects: Metamorphosis Is Not a New Beginning. Integrative and Comparative Biology, $46: 323-333$. 
Pechenik, J. A., R. Berard, D. D. Gleason, T. R. Gleason, and D. Champlin. 2001. Influence of Lowered Salinity and Elevated Cadmium on the Survival and Metamorphosis of Trochophores in Capitella sp. Invertebrate Biology, 120:142-148.

Pechenik, J. A., D. E. Wendt, and J. N. Jarrett. 1998. Metamorphosis Is Not a New Beginning. Bioscience, 48:901-910.

Putnam, H. M., P. J. Edmunds, and T.-Y. Fan. 2008. Effect of Temperature on the Settlement Choice and Photophysiology of Larvae from the Reef Coral Stylophora pistillata. Biological Bulletin, 215:135-142.

Raimondi, P. T., and A. N. C. Morse. 2000. The Consequences of Complex Larval Behavior in a Coral. Ecology, 81:3193-3211.

Richmond, R. H. 1987. Energetics, Competency, and Long-Distance Dispersal of Planula Larvae of the Coral Pocillopora damicornis. Marine Biology, 93:527-533.

- 1993a. Coral Reefs: Present Problems and Future Concerns Resulting from Anthropogenic Disturbance. American Zoologist, 33:524-536.

- 1993b. Effects of Coastal Runoff on Coral Reproduction. In Proceedings of the Colloquium and Forum on Global Aspects of Coral Reefs: Health, Hazard, and History, ed. R. N. Ginsburg, pp. 360-364. University of Miami, Miami, Fla.

-1997. Reproduction and Recruitment in Corals: Critical Links in the Persistence of Reefs. In Life and Death of Coral Reefs, ed. C. E. Birkeland, pp. 175-198. New York: Chapman \& Hall.

Richmond, R. H., and C. L. Hunter. 1990. Reproduction and Recruitment of Corals: Comparisons among the Caribbean, the Tropical Pacific, and the Red Sea. Marine Ecology Progress Series, 60:185-203.

Richmond, R. H., T. Rongo, Y. Golbuu, S. Victor, N. Idechong, G. Davis, W. Kostka, L. Neth, M. Hamnett, and E. Wolanski. 2007. Watersheds and Coral Reefs: Conservation Science, Policy, and Implementation. Bioscience, 57:598-607.

Rinkevich, B., and Y. Loya. 1987. Variability in the Pattern of Sexual Reproduction of the Coral Stylophora pistillata at Eilat, Red-Sea: A Long-Term Study. Biological Bulletin, 173:335-344.

Roberts, R. D., and C. Lapworth. 2001. Effect of Delayed Metamorphosis on Larval Competence, and Post-Larval Survival and Growth, in the Abalone Haliotis iris Gmelin. Journal of Experimental Marine Biology and Ecology, 258:1-13.

Rylaarsdam, K.W. 1983. Life Histories and Abundance Patterns of Colonial Corals on Jamaican Reefs. Marine Ecology Progress Series, 13:249-260.

Sammarco, P. W. 1985. The Great Barrier Reef Versus the Caribbean: Comparisons of Grazers, Coral Recruitment Patterns and Reef Recovery. In Proceedings of the 5th International Coral Reef Symposium, 4:391-398.

Sammarco, P. W., and J. C. Andrews. 1988. Localized Dispersal and Recruitment in Great Barrier Reef Corals: The Helix Experiment. Science, 239:1422-1424.

Sammarco, P. W., and J. H. Carleton. 1981. Damselfish Territoriality and Coral Community Structure: Reduced Grazing, Coral Recruitment, and Effects on Coral Spat. In: Proceedings of the 4th International Coral Reef Symposium, 2:525-535.

Sebens, K. P. 1982. Competition for Space: Growth Rate, Reproductive Output, and Escape in Size. American Naturalist, 120:189-197.

Smith, J. E., M. Shaw, R. A. Edwards, D. Obura, O. Pantos, E. Sala, S. A. Sandin, S. Smriga, M. Hatay, and F. L. Rohwer. 2006. Indirect Effects of Algae on Coral: Algae-Mediated, Microbe-Induced Coral Mortality. Ecology Letters, 9:835-845.

Smith, S. R. 1992. Patterns of Coral Recruitment and Post-settlement Mortality on Bermuda's Reefs: Comparisons to Caribbean and Pacific Reefs. American Zoologist, 32:663-673.

- 1997. Patterns of Coral Settlement, Recruitment and Juvenile Mortality with Depth at Conch Reef, Florida. Proceedings of the 8th International Coral Reef Symposium, 2:1197-1202.
Steneck, R. S. 2006. Staying Connected in a Turbulent World. Science, 311:480-481.

Steneck, R. S., and J. C. Lang. 2003. Rapid Assessment of Mexico's Yucatan Reef in 1997 and 1999: Pre- and Post-Mass Bleaching and Hurricane Mitch (Stony Corals, Algae and Fish). Atoll Research Bulletin, 496:294-317.

Steneck, R. S., and M. N. Dethier. 1994. A Functional Group Approach to the Structure of Algal-Dominated Communities. Oikos, 69:476-498.

Strathmann, R. R., T. R. Hughes, A. M. Kuris, K. C. Lindeman, S. G. Morgan, J. M. Pandolfi, and R. R. Warner. 2002. Evolution of Local Recruitment and Its Consequences for Marine Populations. Bulletin of Marine Science, 70:377-396.

Styan, C. A. 1998. Polyspermy, Egg Size, and the Fertilization Kinetics of Free-Spawning Marine Invertebrates. American Naturalist, 152:290-297.

Sullivan, B., D. J. Faulkner, and L. Webb. 1983. Siphonodictidine, a Metabolite of the Burrowing Sponge Siphonodictyon sp. That Inhibits Coral Growth. Science, 221:1175-1176.

Suzuki, G., T. Hayashibara, Y. Shirayama, and H. Fukami. 2008. Evidence of Species-Specific Habitat Selectivity of Acropora Corals Based on Identification of New Recruits by Two Molecular Markers. Marine Ecology Progress Series, 355:149-159.

Szmant, A. M. 1986. Reproductive Ecology of Caribbean Reef Corals. Coral Reefs, 5:43-53.

Szmant, A. M., and N. J. Gassman. 1990. The Effects of Prolonged Bleaching on the Tissue Biomass and Reproduction of the Reef Coral Montastraea annularis. Coral Reefs, 8:217-224.

Thiyagarajan, V., L. A. Gosselin, and P. Y. Qian. 2008. Juvenile Growth in Barnacles: Combined Effect of Delayed Metamorphosis and Sublethal Exposure of Cyprids to Low-Salinity Stress. Marine Ecology Progress Series, 344:173-184.

Thiyagarajan, V., T. Harder, J. W. Qiu, and P. Y. Qian. 2003. Energy Content at Metamorphosis and Growth Rate of the Early Juvenile Barnacle Balanus amphitrite. Marine Biology, 143:543-554.

Tomaiuolo, M., T. F. Hansen, and D. R. Levitan. 2007. A Theoretical Investigation of Sympatric Evolution of Temporal Reproductive Isolation as Illustrated by Marine Broadcast Spawners. Evolution, 61:2584-2595.

Van Moorsel, G. W. N. M. 1989. Juvenile Ecology and Reproductive Strategies of Reef Corals. Leiden: Backhuys Publishers.

Vermeij, M. J. A. 2005. Substrate Composition and Adult Distribution Determine Recruitment Patterns in a Caribbean Brooding Coral. Marine Ecology Progress Series, 295:123-133.

- 2006. Early Life-History Dynamics of Caribbean Coral Species on Artificial Substratum: The Importance of Competition, Growth and Variation in Life-History Strategy. Coral Reefs, 25:59-71.

Vermeij, M. J. A., N. D. Fogarty, and M. W. Miller. 2006. Pelagic Conditions Affect Larval Behavior, Survival, and Settlement Patterns in the Caribbean Coral Montastraea faveolata. Marine Ecology Progress Series, 310:119-128.

Vermeij, M. J. A., and S. A. Sandin. 2008. Density-Dependent Settlement and Mortality Structure: The Earliest Life Phases of a Coral Population. Ecology, 89:1994-2004.

Vermeij, M. J. A., J. E. Smith, C. M. Smith, R. V. Thurber, and S. A. Sandin. 2009. Survival and Settlement Success of Coral Planulae: Independent and Synergistic Effects of Macroalgae and Microbes. Oecologia, 159:325-336.

Wakeford, M., T. J. Done, and C. R. Johnson. 2008. Decadal Trends in a Coral Community and Evidence of Changed Disturbance Regime. Coral Reefs, 27:1-16.

Webster, N. S., L. D. Smith, A. J. Heyward, J. E. M. Watts, R. I. Webb, L. L. Blackall, and A. P. Negri. 2004. Metamorphosis of a Scleractinian Coral in Response to Microbial Biofilms. Applied and Environmental Microbiology, 70:1213-1221. 
Wendt, D. E. 1998. Effect of Larval Swimming Duration on Growth and Reproduction of Bugula neritina (Bryozoa) under Field Conditions. Biological Bulletin, 195:126-135.

Williams, D. E., M. W. Miller, and K. L. Kramer. 2008. Recruitment Failure in Florida Keys Acropora palmata, a Threatened Caribbean Coral. Coral Reefs, 27:697-705.

Willis, B. L., R. Babcock, P. L. Harrison, and T. K. Oliver. 1985. Patterns in Mass Spawning of Corals on the Great Barrier Reef from 1981 to 1984. In Proceedings of the 5th International Coral Reef Symposium, 4:343-348.

Willis, B. L., R. C. Babcock, P. L. Harrison, and C. C. Wallace. 1997. Experimental Hybridization and Breeding Incompatibilities within the Mating Systems of Mass Spawning Reef Corals. Coral Reefs, 16:S53-S65.
Willis, B. L., M. van Oppen, D. J. Miller, S. V. Vollmer, and D. J. Ayre. 2006. The Role of Hybridization in the Evolution of Reef Corals. Annual Review of Ecology, Evolution, and Systematics, 37:489-517.

Wittenberg, M., and W. Hunte. 1992. Effects of Eutrophication and Sedimentation on Juvenile Corals I. Abundance, Mortality and Community Structure. Marine Biology, 112:131-138.

Wolstenholme, J. K. 2004. Temporal Reproductive Isolation and Gametic Compatibility Are Evolutionary Mechanisms in the Acropora humilis Species Group (Cnidaria; Scleractinia). Marine Biology, 144:567-582.

Zigler, K. S., M. A. McCartney, D. R. Levitan, and H. A. Lessios. 2005. Sea Urchin Bindin Divergence Predicts Gamete Compatibility. Evolution, 59:2399-2404. 